\title{
Structural evolution of the Day Nui Con Voi metamorphic complex: Implications on the development of the Red River Shear Zone, Northern Vietnam
}

\author{
Meng-Wan Yeh ${ }^{\mathrm{a}, *, 1}$, Tung-Yi Lee ${ }^{\mathrm{b}}$, Ching-Hua Lo ${ }^{\mathrm{c}}$, Sun-Lin Chung ${ }^{\mathrm{c}}$, Ching-Ying Lan ${ }^{\mathrm{d}}$, Tran Tuan Anh ${ }^{\mathrm{e}}$ \\ ${ }^{a}$ Center for General Education, National Taiwan Normal University, Taipei, Taiwan \\ ${ }^{\mathrm{b}}$ Department of Earth Sciences, National Taiwan Normal University, Taipei, Taiwan \\ ${ }^{\mathrm{c}}$ Department of Geology, National Taiwan University, Taipei, Taiwan \\ ${ }^{\mathrm{d}}$ Institute of Earth Science, Academia Sinica, Taipei, Taiwan \\ ${ }^{\mathrm{e}}$ Institute of Geology, National Centre for Natural Science and Technology, Viet Nam
}

\section{A R T I C L E I N F O}

\section{Article history:}

Received 30 October 2007

Received in revised form 1 August 2008

Accepted 23 August 2008

Available online 18 September 2008

\section{Keywords:}

Red River Shear Zone

Dai Nui Con Voi

Structure

Tectonics

\begin{abstract}
A B S T R A C T
The Day Nui Con Voi (DNCV) metamorphic complex in North Vietnam is the southernmost high-grade metamorphic zone along the NW-SE trending Red River Shear Zone (RRSZ) in Indochina. The RRSZ was considered as a classical large-scale continental strike-slip fault that had played a significant role in the continental extrusion of Southeast Asia since the collision of India and Eurasia. Earlier ideas determined the RRSZ as a steep shear zone that penetrated the entire lithosphere. Both metamorphism and structures within rocks along the DNCV metamorphic complex have been previously thought to be formed syn-tectonically by left-lateral shearing of the RRSZ during the Oligocene-Miocene continental escape tectonics. However, our meso- and microstructural re-examination of this region shows that these metamorphic rocks were formed during earlier tectonic episodes unrelated to strike-slip shearing. High angle to near orthogonal overprinting fabrics indicated that this region recorded three episodes of ductile deformation followed by brittle faulting events with different intensity spanning from the Triassic to the Tertiary. $\mathrm{D}_{1}$ is preserved as NW-SE striking upright folds under garnet grade regional metamorphism during the Triassic Indosinian orogeny as South China block amalgamated with the Indochina block. The large-scale horizontal $\mathrm{D}_{2}$ folds with a dominant top to N-NW bottom to S-SW sense of shear, and subhorizontal fold axial planes suggest that the DNCV metamorphic complex remained at midcrustal depths since the Indosinian orogeny. The youngest ductile deformation event, $D_{3}$, refolded $D_{2}$ recumbent folds into a dome, and uplifted the DNCV as lower-temperature fabrics, $S_{3}$, indicated. Steep mylonite zones with left-lateral kinematic indicators and brittle faulting were developed on both limbs of the dome along the steep Song Hong and Song Chay faults during left-lateral movement of the RRSZ. Our new spatial, temporal and kinematic correlations of metamorphic fabrics within the DNCV metamorphic complex support the suggestion that the RRSZ developed after regional metamorphism and remained purely a crustal fault. The complicated deformation history recorded within the DNCV metamorphic complex provides an alternative interpretation and suggests that crustal scale strike-slip faults (such as the RRSZ) need not root from the mantle.
\end{abstract}

(ㄷ) 2008 Elsevier Ltd. All rights reserved.

\section{Introduction}

The indentation-extrusion tectonic model proposed by Tapponnier et al. $(1982,1986)$ stated that as a consequence to the India-Eurasia collision, large coherent continental masses extruded along major strike-slip faults which resulted in a large portion of

\footnotetext{
* Corresponding author. Center for General Education, National Taiwan Normal University, No. 162 East Hoping Rd, Section 1 Taipei 10610, Taiwan, ROC. Tel.: +886 22934 7120x63; fax: +88622933 3315.

E-mail address: marywyeh@ntnu.edu.tw (M.-W. Yeh).

1 Current address: The Center for General Education, National Taiwan Normal University, Taipei, Taiwan.
}

the deformation visible in Asia. The Cenozoic tectonic evolution of the Red River Shear Zone (RRSZ) is of crucial importance, being one of the largest strike-slip faults in Southeast Asia. However, critical factors, such as the total finite offsets, timing of strike-slip motion and scale of the fault (crust or mantle) remain controversial (e.g., Molnar and Tapponnier, 1975; Harrison et al., 1992, 1996; Lacassin et al., 1993; Leloup et al., 1995, 2001a,b, 2007; Tapponnier et al., 1982, 1990; Wang et al., 1998, 2000, 2001; Nagy et al., 2001; Jolivet et al., 2001; Gilley et al., 2003; Searle, 2006, 2007; Anczkiewicz et al., 2007; Viola and Anczkiewicz, 2008). The indentationextrusion model treats the continental lithosphere as a rigid medium with deformation concentrated along major deep rooted strike-slip faults that cut through the entire lithosphere, while little 
to no deformation occurred between (Tapponnier et al., 1982, 1986, 1990). England and McKenzie (1982), Burchfiel et al. (1989), Wang and Burchfiel (1997), and Jolivet et al. (2001) challenged this assumption and advocated a horizontal shear zone at midcrustal level as a detachment root for these major strike-slip faults while the strike-slip faults are purely crustal. The key issue to this debate is whether the upper crust is mechanically decoupled from the underlying lower crust-mantle by sub-horizontal detachment faults (Jolivet et al., 2001; Searle, 2006). Correlating flat-lying foliations formed under high-T sillimanite-grade conditions with steep post-sillimanite shear bands formed under low-T conditions, observed in the core of the Dan Nui Con Voi (DNCV) antiformal dome along the RRSZ, Jolivet et al. (2001) and Searle (2006, 2007) interpreted that low temperature deformation was localized in the upper crust, and that the RRSZ must root in a horizontal shear zone at a midcrustal level. Since shear heating alone could not result in high-grade metamorphic conditions as observed in the DNCV metamorphic complex, Searle (2006) also argued that vertical strike-slip shearing of the RRSZ occurred after metamorphism and granite emplacement.

As Jolivet et al. (2001) and Searle (2006) showed for the DNCV, an important requirement for understanding the development of shear complexes and processes of crustal deformation is the comprehension of relative timing of metamorphism, magmatism and deformation. Porphyroblasts-matrix microstructural relationships can provide useful information on a wide range of geological problems, including: (1) metamorphic P-T-t paths; (2) relative timing between deformation, metamorphism and magmatism; and (3) shear senses during foliation development (e.g., Bell and Rubenach, 1983; Bell et al., 1986, 1998; Johnson and Vernon, 1995). One of the requirements for successfully using foliation and porphyroblast relations is the identification of the number of fabricforming events and the relative timing between these events and porphyroblast growth. The relative timing of metamorphism and deformation events can be resolved through the systematic use of cross-cutting relationships of multiple foliations and porphyroblasts (e.g., Bell and Rubenach, 1983; Davis and Forde, 1994). Within this context, sample collection and structural observation were made along major roads parallel to, and crossing the DNCV metamorphic complex in five sub-regions: Lao Cai, Bao Ha, Yan Bai, Viet Tri and Nam Dinh (Fig. 1). Detailed macro- and microstructural correlation of these samples has established a lengthy structural evolution of the DNCV metamorphic complex in Northern Vietnam. This has allowed the reevaluation of tectonic models that link Oligocene-Miocene left-lateral movement.

\section{Geological setting}

The $\sim 30 \mathrm{~km}$ wide, $250 \mathrm{~km}$ long, NW-SE trending DNCV metamorphic complex in Northern Vietnam is the southernmost of four elongated metamorphic segments (Xuelong Shan, Diancang Shan, Ailao Shan in China, and DNCV in Vietnam) of the RRSZ. The DNCV metamorphic complex merges with the Ailao Shan from Lao Cai to the north and plunges under the Quaternary Song Hong Delta plain to the south around Viet Tri, and is bounded against NeogeneQuaternary basins on both sides by the NW-SE trending, steeply (ca. $70^{\circ}$ ) NE dipping, Song Hong and Song Chay strike-slip faults (Fig. 1). The DNCV consists mainly of amphibolite, migmatite, garnet-biotite-sillimanite gneiss, garnet bearing schists and marbles. It contains well-developed foliations that mostly strike NW-SE, parallel to the general trend of the RRSZ. Petrological and thermobarometric studies revealed two deformation stages, at amphibolite facies (690 ${ }^{\circ} \mathrm{C}$ and 6-7 kbar; Nam et al., 1998), up to $780-830^{\circ} \mathrm{C}$ and $7.5-8.8 \mathrm{kbar}$ (Gilley et al., 2003) or between $700-$ $800{ }^{\circ} \mathrm{C}$ and 5-9 kbar (Anczkiewicz et al., 2007) and greenschist facies $\left(480^{\circ} \mathrm{C},<3 \mathrm{kbar}\right.$; Nam et al., 1998). These data indicate intense deformation and deep metamorphic conditions, which are equivalent to $\sim 30 \mathrm{~km}$ of depth during the peak metamorphism (Searle, 2006). Thermochronological results are complex to interpret but indicate metamorphism since the Triassic (Nam et al., 1998; Maluski et al., 2001; Gilley et al., 2003). Exhumation and cooling remained slow till 28 Ma. (Harrison et al., 1996; Wang et al., $1998,2000,2001)$, followed by rapid cooling and further exhumation to $21 \mathrm{Ma}$, and after $5 \mathrm{Ma}$ (Burchfiel and Wang, 2003; Burchfiel, 2004).

\subsection{Cenozoic activity of RRSZ - Vietnam portion}

Recent geochronological studies have revealed the occurrence of two tectonothermal episodes during Triassic (Maluski et al., 1995, 2001; Lepvrier et al., 1997; Nam, 1998; Nam et al., 2003) and Tertiary (Tapponnier et al., 1990; Scharer et al., 1990, 1994; Wang et al., 1998, 2000; Jolivet et al., 1999; Gilley et al., 2003; Searle, 2006) for the Vietnam portion of RRSZ. The Tertiary tectonothermal episode is composed of two periods of Cenozoic strike-slip motion that are generally considered to be most influential in the geological evolution of the RRSZ. One is the large-scale sinistral strike-slip displacement of the RRSZ as Indochina extruded southeastwardly during Miocene (e.g., Scharer et al., 1990, 1994; Tapponnier et al., 1990; Harrison et al., 1992, 1996; Leloup and Kienast, 1993; Hall, 1996; Chung et al., 1997; Wang et al., 1998, 2000, 2001; Jolivet et al., 2001; Liang et al., 2007). This major left-lateral ductile shear is considered to be responsible for exhuming the high-grade rocks of the DNCV metamorphic complex (Nam, 1998; Nam et al., 1998; Jolivet et al., 2001; Anczkiewicz et al., 2007). Current geomorphologic and geodetic data indicated the RRSZ as a dextral strike-slip fault zone (Allen et al., 1984; Nguyen, 1986; Zhao, 1995; Burchfiel and Wang, 2003). Cong and Feigl (1999) and Jolivet et al. (2001) suggested that the strike-slip motion changed from sinistral to dextral with a normal component during the Late Miocene. Recent geodetic data suggested this right-lateral motion remains unchanged (Cong and Feigl, 1999). However, by estimating horizontal strain rates from GPS measurements across the RRSZ near Thac Ba, Vietnam from 1963 to 2000, Feigl et al. (2003) concluded that the RRSZ is currently inactive.

\section{Structural analysis}

Meso- and microstructural measurements were made on outcrops and oriented thin sections of 25 samples composed of gneiss, schist, amphibolite and mylonite through the Lao Cai, Bao Ha, Yen Bai, Viet Tri and Nam Dihn regions (Fig. 1 and Table 1). Two transects across the complex were conducted along roads between Bao Yan to Bao Ha (Route 279), and between Yen Bine to Yen Bai, respectively. Consistent deformation patterns and sequences were noted through all study areas from Lao Cai to Nam Dinh suggesting that the DNCV metamorphic complex experienced the same deformation condition throughout its length in Vietnam.

\subsection{Field relationships and mesoscopic structures}

The most dominant structural feature seen in all outcrops are refolded sub-horizontal isoclinal folds $\left(\mathrm{F}_{2}\right)$ with sub-horizontal to shallowly plunging NW-SE trending stretching lineations (Fig. 2). Sub-horizontal to shallow dipping axial planes $\left(\mathrm{S}_{2}\right)$ are folded by steep NW-SE striking axial planes $\left(\mathrm{S}_{3}\right)$, which form open to tight antiform-domal structures $\left(\mathrm{F}_{3}\right)$. Both limbs of the NW-SE trending upright $F_{3}$ antiformal dome are bounded by two well-developed mylonite zones parallel to the Song Hon and Song Ca faults. Understanding the spatial and temporal relationships of these macroscopic folds within multiply deformed terrains provides important constraints on tectonic models of continental collision. 


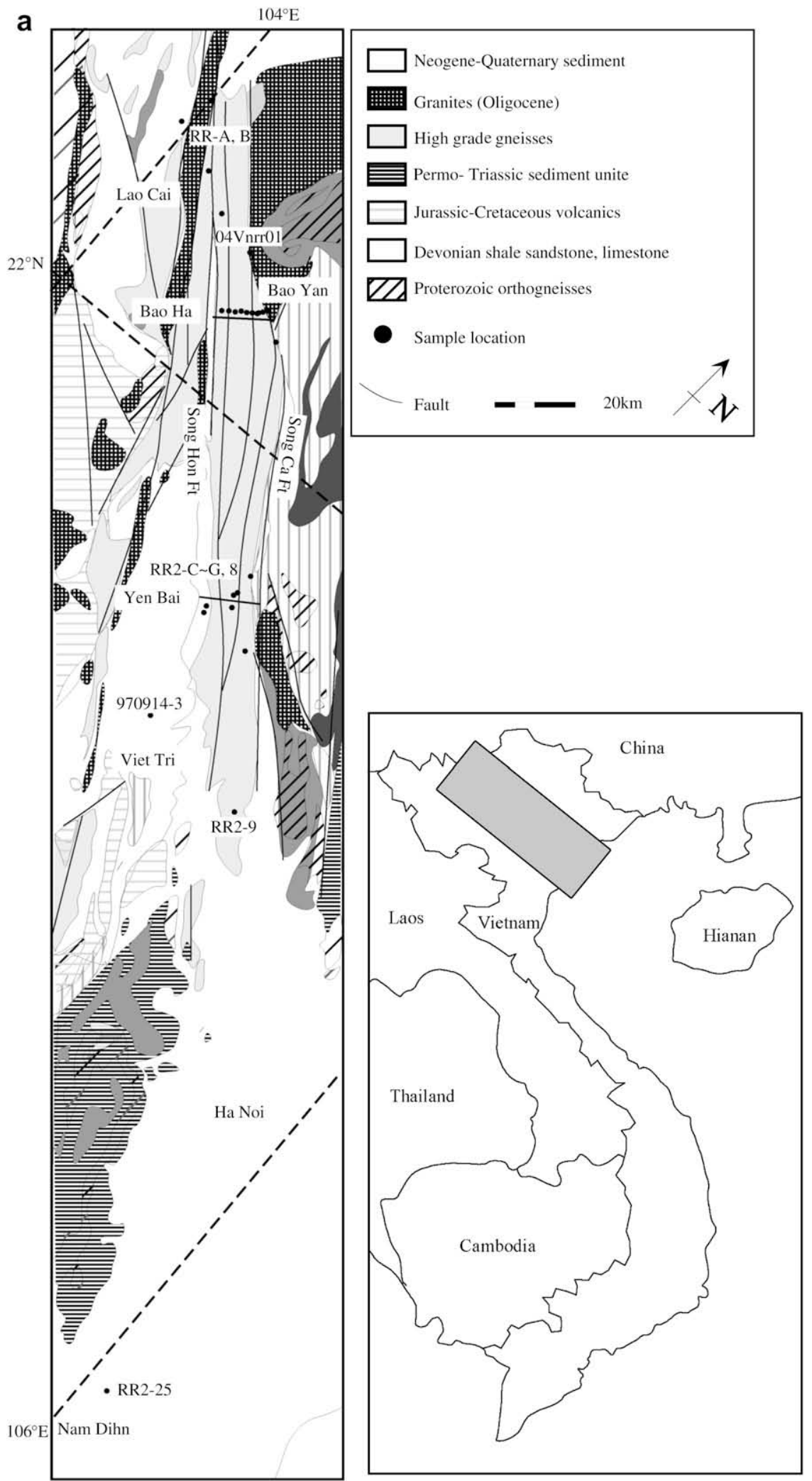

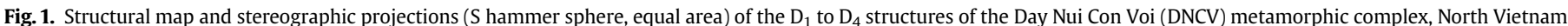

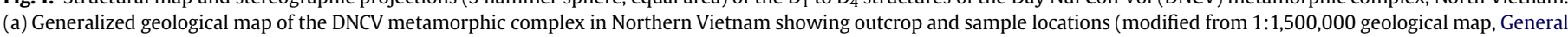

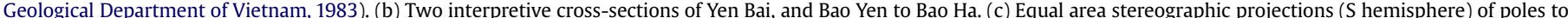

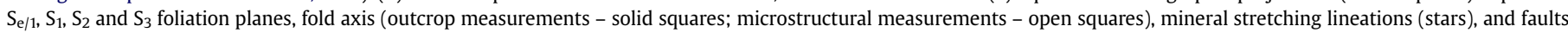

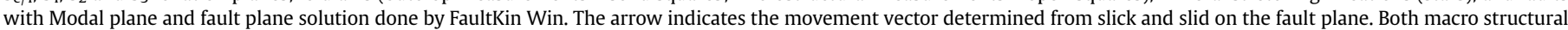
and microstructural measurements showed the same pattern that $S_{2}$ foliation shows a cylindrical folding pattern, and the stretching lineation is parallel to the $D_{3}$ fold axes. 
b
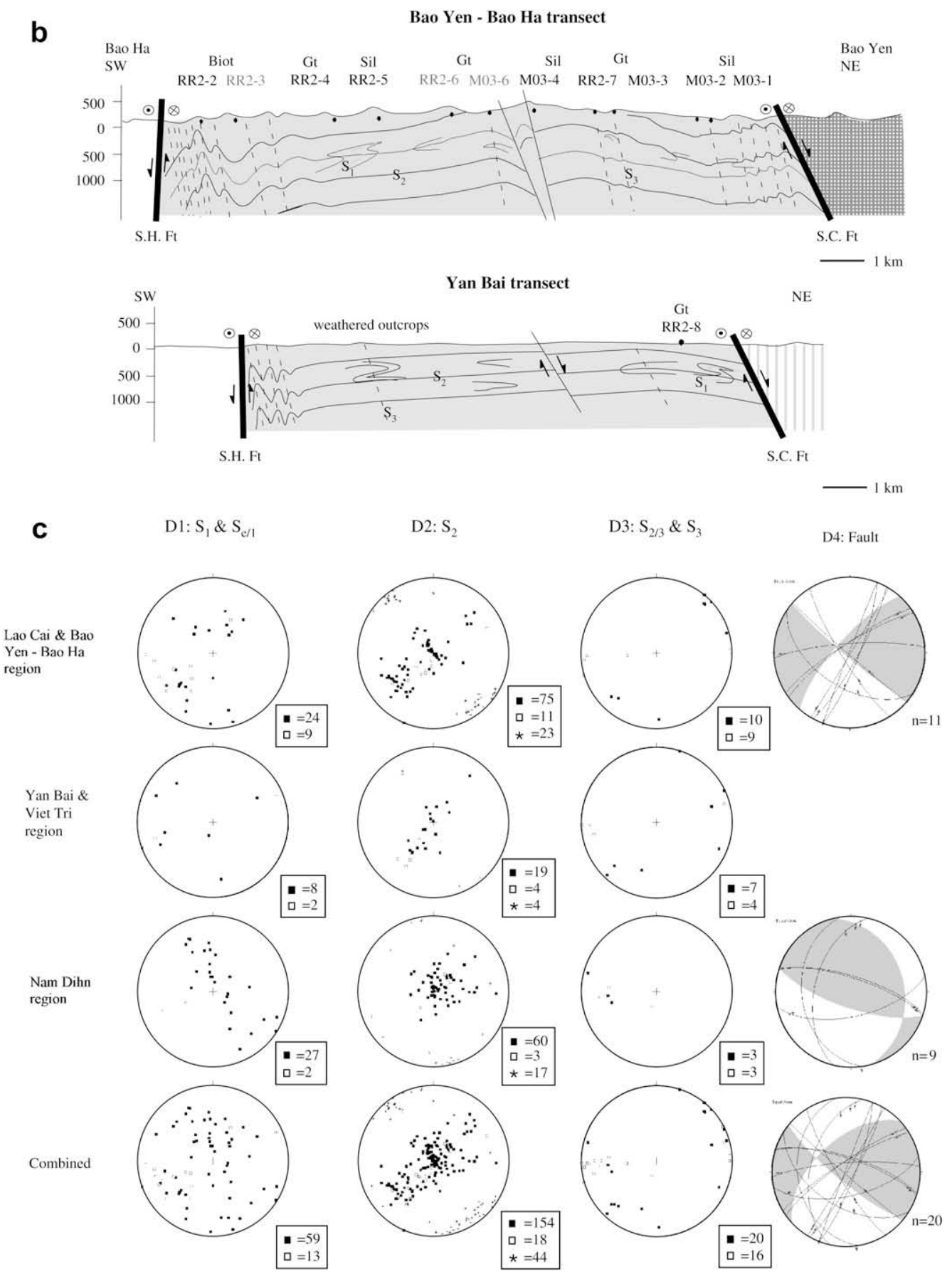

Fig. 1. (continued).

Correctly dating such folds relative to the overall deformation history can be difficult. Thus, their timing has generally been determined via mesoscopic analysis of cleavage vergence as a geometric means of determining whether a foliation is subparallel to the axial plane of a macroscopic fold, assuming the fold and axial plane cleavage formed during the same deformation event (Hobbs et al., 1976).

Throughout the Bao Ha to Bao Yan transect, all outcrops contain tight centimeter to meter scale matrix parallel isoclinal folds $\left(\mathrm{F}_{2}\right)$ that are folded into NW-SE open upright folds $\left(\mathrm{F}_{3}\right)$ with NW-SE trending sub-horizontal mineral stretching lineation showing type twofold interference pattern (Ramsay, 1967; Fig. 2). The original orientation of the early $F_{2}$ axial planes $\left(S_{2}\right)$ measured from $F_{3}$ hinges and regions less affected by the $\mathrm{F}_{3}$ folding event were sub-horizontal. Similar fold interference patterns were also observed and measured from other regions throughout the DNCV (Fig. 2a) indicating that the DNCV experienced at least two folding events. A few outcrops from the Bao Ha to Bao Yan transect, Yen Bai, Viet Tri and Nam Dihn contain tight isoclinal upright folds $\left(\mathrm{F}_{1}\right)$ with NW-SE sub-vertical axial planes $\left(\mathrm{S}_{1}\right)$ folded by sub-horizontal folds $\left(\mathrm{F}_{2}\right.$; Fig. 2b). We can distinguish these isoclinal folds with NW-SE striking axial planes resulting from an older folding event since these folds were folded by $F_{2}$. Based on superposition relationships, the sequence of deformation was earliest NW-SE upright folds $\left(\mathrm{F}_{1}\right)$ folded/or inclined into tight isoclinal horizontal folds $\left(F_{2}\right)$. The horizontal folds were then folded again into shear zone oblique 
Table 1

Sample list showing their location, rock type and matrix mineral assemblages

\begin{tabular}{|c|c|c|c|c|c|c|c|c|c|c|c|c|c|c|}
\hline Section & Sample no. & Longitude $\left(\mathrm{E}^{\circ}\right)$ & Latitude $\left(\mathrm{N}^{\circ}\right)$ & Rock type & Qt & Plag & Fels & Biot & Muscov & Amph & $\mathrm{Cl}$ & $\mathrm{Gt}$ & $\mathrm{Tm}$ & Sil \\
\hline$\overline{\mathrm{BB}}$ & 04vnrr-1a & 104.34400 & 22.30870 & mylonite & + & - & + & + & fish & - & + & - & - & $\overline{-}$ \\
\hline BB & 04vnrr-1b & 104.34400 & 22.30870 & mylonite & + & - & + & + & fish & - & + & - & - & - \\
\hline BB & RR2-2 & 104.35596 & 22.18238 & mylonite & + & - & + & + & fish & - & + & - & - & - \\
\hline BB & RR2-3A & 104.36530 & 22.18367 & amphibolite & + & + & + & + & - & + & - & - & - & - \\
\hline BB & RR2-3B & 104.36530 & 22.18367 & amphibolite & + & + & + & + & - & + & - & - & - & - \\
\hline BB & RR2-4 & 104.39100 & 22.19946 & gneiss & + & + & + & + & - & - & - & + & - & + \\
\hline BB & RR2-5A & 104.39174 & 22.19858 & gneiss & + & + & + & + & - & - & - & + & - & + \\
\hline BB & RR2-5B & 104.39174 & 22.19858 & gneiss & + & + & + & + & - & - & - & + & - & + \\
\hline BB & RR2-6A & 104.41354 & 22.21035 & amphibolite & + & + & + & + & - & + & - & + & - & - \\
\hline BB & RR2-6B & 104.41354 & 22.21035 & amphibolite & + & + & + & + & - & + & - & - & - & - \\
\hline BB & M03-6b & 104.41420 & 22.21060 & amphibolite & + & + & + & + & - & + & + & + & - & - \\
\hline BB & M03-4 & 104.43390 & 22.21840 & gneiss & + & + & + & + & - & - & + & + & - & + \\
\hline BB & M03-3 & 104.45020 & 22.23100 & gneiss & + & + & + & + & - & - & + & + & - & + \\
\hline BB & M03-1A & 104.45040 & 22.23530 & gneiss & + & + & + & + & - & - & - & + & - & + \\
\hline BB & M03-1B & 104.45040 & 22.23530 & gneiss & + & + & + & + & - & - & - & + & - & + \\
\hline BB & M03-2 & 104.45200 & 22.23390 & gneiss & + & + & + & + & - & - & - & + & - & + \\
\hline BB & RR2-1 & 104.53278 & 22.20355 & gneiss & + & + & + & + & - & - & + & - & - & - \\
\hline YB & 9709143 & 104.90806 & 21.79917 & gneiss & + & + & + & + & - & - & + & + & - & + \\
\hline YB & RR2-8 & 104.90854 & 21.80000 & gneiss & + & + & + & + & - & - & + & + & - & + \\
\hline YB & RR2-9A & 105.30664 & 21.40876 & gneiss & + & + & + & + & - & - & - & + & - & - \\
\hline YB & RR2-9B & 105.30664 & 21.40876 & gneiss & + & + & + & + & - & - & + & + & - & - \\
\hline VT & RR2-7 & 104.45019 & 22.23098 & gneiss & + & + & + & + & - & - & + & + & - & - \\
\hline NB & 07yb005a & 106.07420 & 20.32900 & gneiss & + & + & + & + & + & - & - & + & + & + \\
\hline NB & M03-25a & 106.07680 & 20.32990 & gneiss & + & + & + & + & + & - & - & + & + & + \\
\hline NB & M03-25b & 106.07680 & 20.32990 & gneiss & + & + & + & + & + & - & - & + & + & + \\
\hline
\end{tabular}

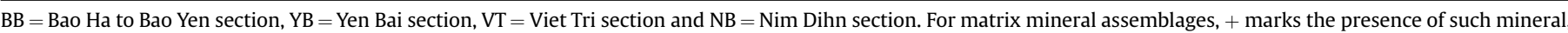

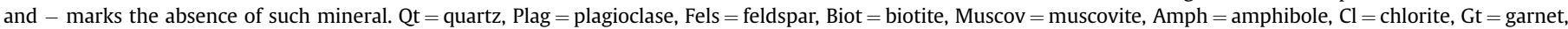
$\mathrm{Tm}=$ turmaline, Sil $=$ sillimanite .

(NNW-SSE to N-S) antiformal domes bounded by shear zone parallel mylonite zones along both limbs. All these folds were then cut by left-lateral and normal faults. Conjugating NE-SW trending right-lateral faults were also recorded (Fig. 1) indicating that brittle deformation occurred after ductile deformation.
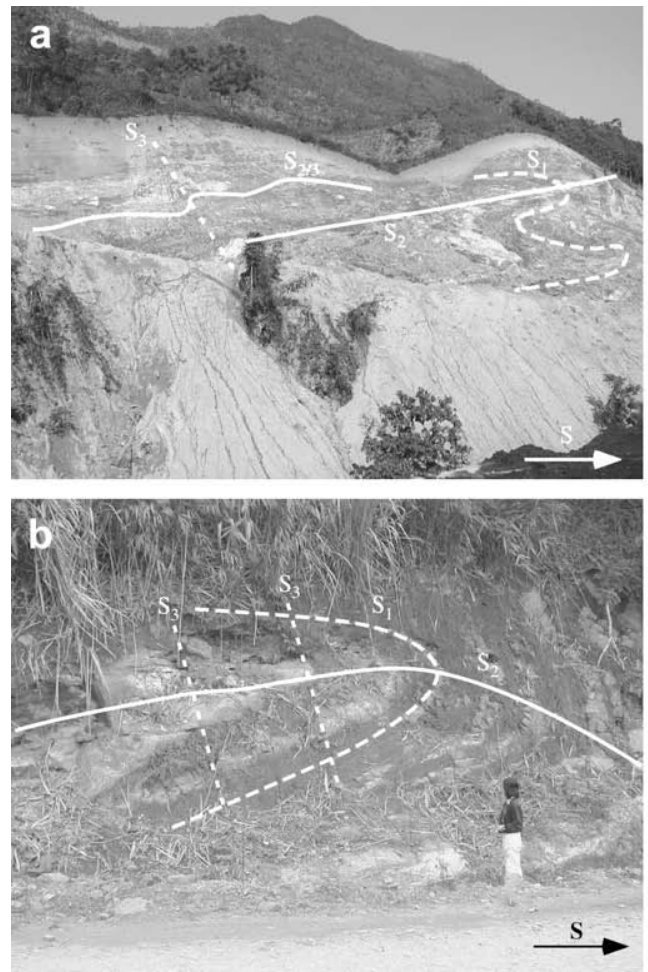

\subsection{Microstructural relationships}

The gneiss samples usually contain a strong schistosity marked by biotite, quartz, and sillimanite ribbons (Fig. 3a and c). Overprinting relations between four matrix fabrics $\left(S_{e / 1}, S_{1}, S_{2}\right.$ and
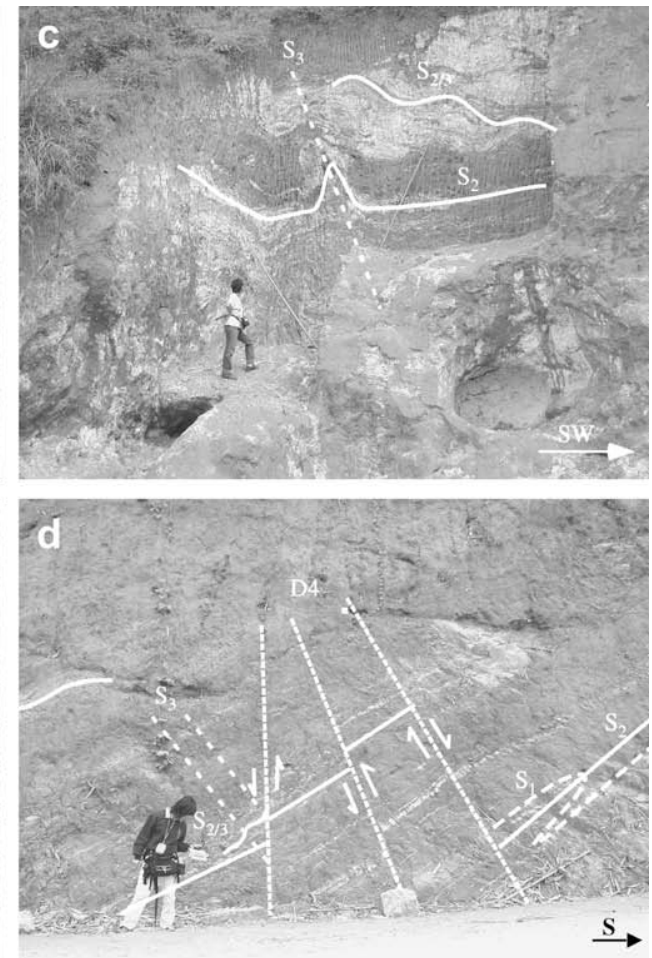

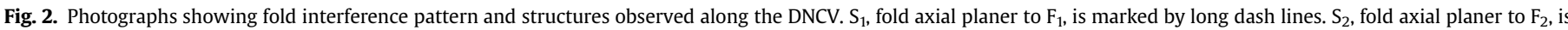

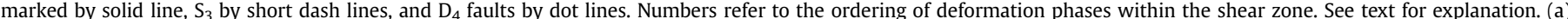

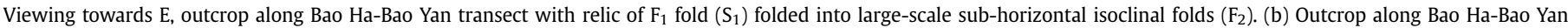

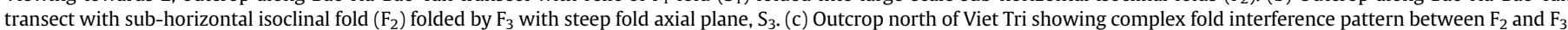

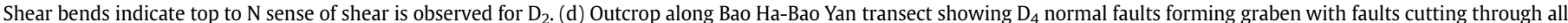
other structures: $S_{1}, S_{2}$ and $S_{3}$. 


\section{a}
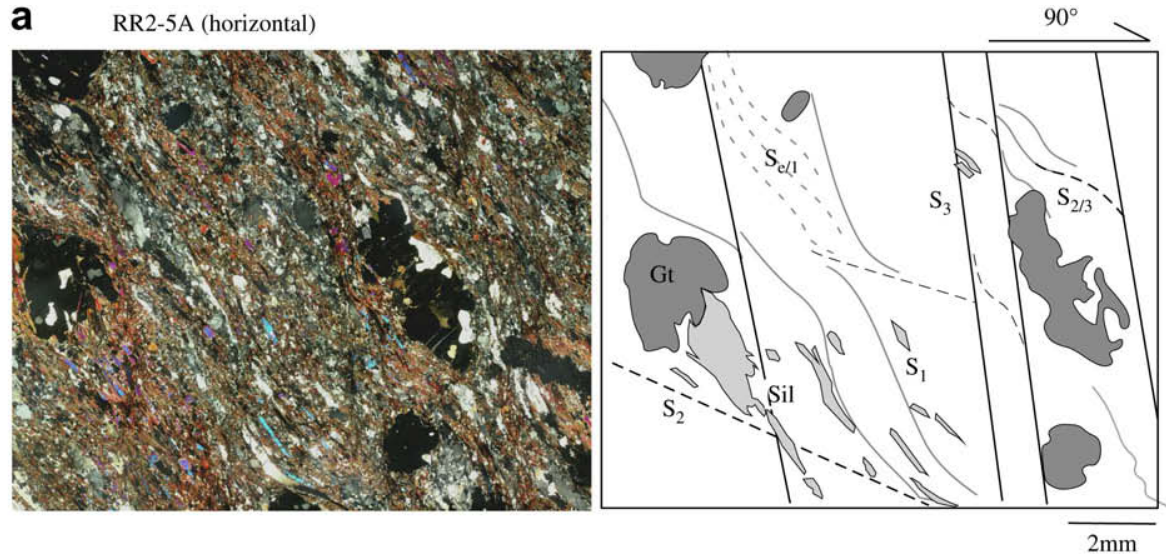

RR2-5A (vertical)
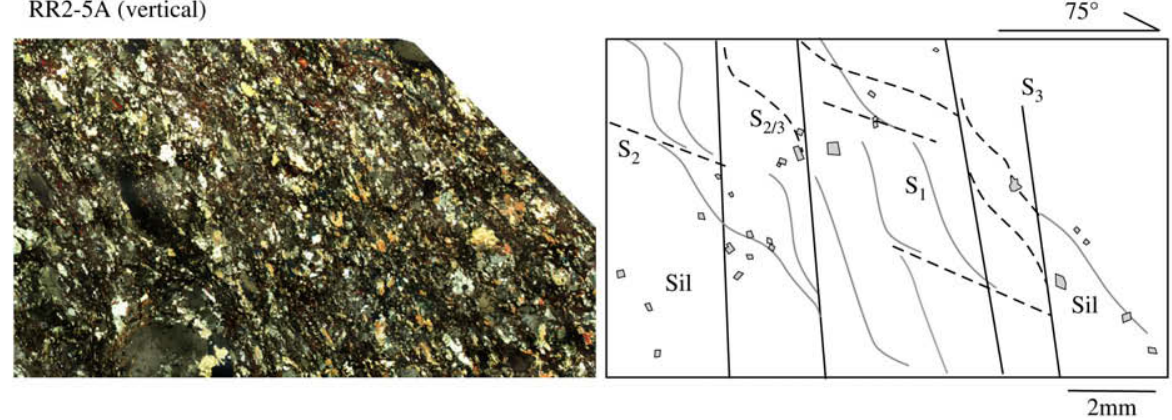

b RR2-2 (horizontal)

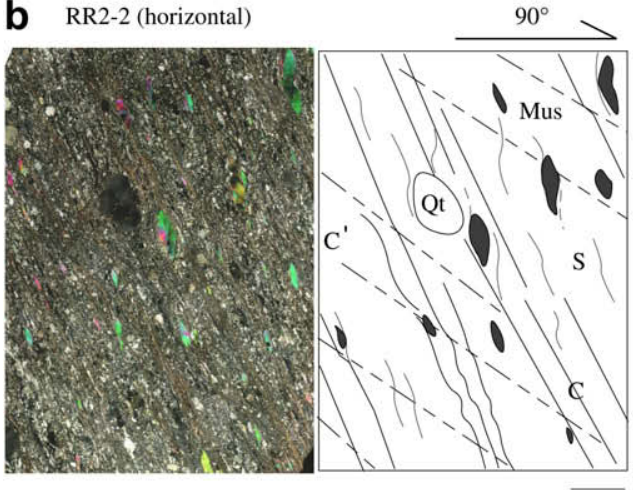

RR2-2 (vertical)
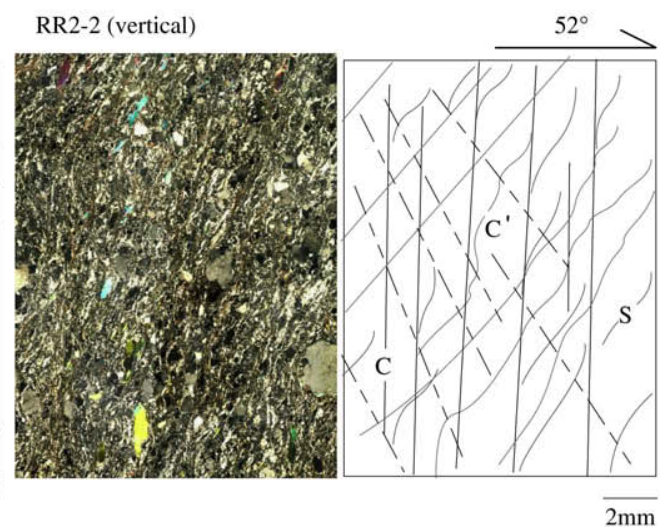

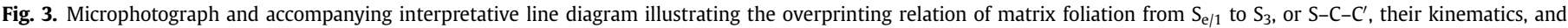

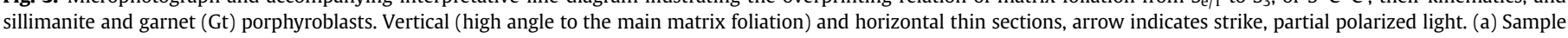

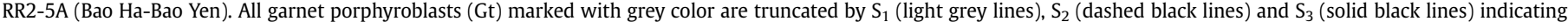

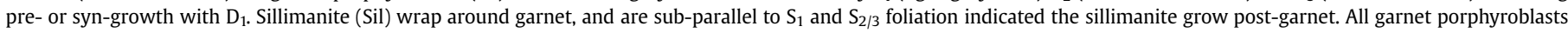

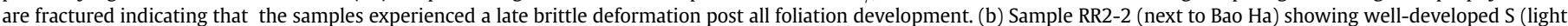

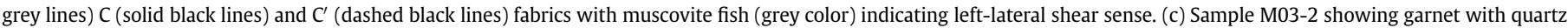

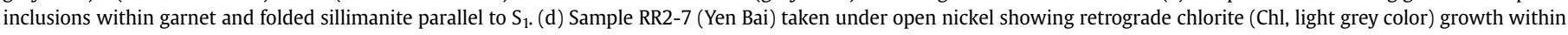

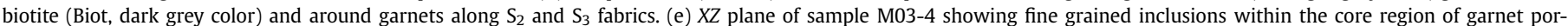
phyroblasts within inclusion-free rim, which suggest that there might be two growth stages.

$\mathrm{S}_{3}$; Fig. 3), which possibly correspond to the folding events described above, were observed meso- and microscopically. We use the denotation $\mathrm{S}_{\mathrm{e} / 1}$ to indicate the oldest foliation observed that was reactivated or deformed by $\mathrm{D}_{1}$ or later deformation events. The earliest shallow NE dipping schistosity $\mathrm{S}_{\mathrm{e} / 1}$ (Fig. 3a) was only observed under the microscope. By looking towards $\mathrm{N}$ on vertical sections cutting perpendicular to lineation and dominant matrix foliation, $\mathrm{S}_{\mathrm{e} / 1}$ is striking NW-SE and shallowly dipping towards NE (Fig. 2). They are preserved as crenulated cleavages with sigmoidal shapes showing dominant clockwise (or " $\mathrm{S}$ ") asymmetry from flat to steep (Fig. 5a) between the seams of differentiated cleavage, $S_{1}$, on both vertical and horizontal thin sections (Fig. 5a). Steeply NE dipping $S_{1}$ is axial planar to macroscopic upright NW-SE trending folds $\left(F_{1}\right)$, and generally consists of strongly differentiated quartz and mica layers (Fig. 3). The $S_{1}$ fabrics occur as open crenulated cleavages with sigmoidal shapes with an exclusive counter clockwise (or " $Z$ ") asymmetry from steep to flat (Fig. 5b) between the seams of differentiated cleavage, $\mathrm{S}_{2}$, on both horizontal and vertical thin sections looking towards $\mathrm{N}$ (Fig. 5b). $\mathrm{S}_{2}$ is generally NW-SE striking sub-horizontal to shallowly NE dipping, axial planer to the macroscopic sub-horizontal folds $\left(\mathrm{F}_{2}\right)$ dipping both towards $\mathrm{NE}$ and SW (Fig. 2). $S_{2}$ is locally intensely developed into differentiated crenulation cleavage with exclusive clockwise (or "S") asymmetry from flat to steep (Fig. 5c) on horizontal thin sections yet opposite asymmetries across $\mathrm{F}_{3}$ fold limbs on vertical thin sections (Fig. $5 \mathrm{c}$ ) by the $F_{3}$ event. $S_{3}$ is a very weak crenulation cleavage, which lies axial plane to macroscopic upright NW-SE trending folds $\left(\mathrm{F}_{3}\right.$; Fig. 3). The mylonite samples show well-developed $S / C$ fabrics 

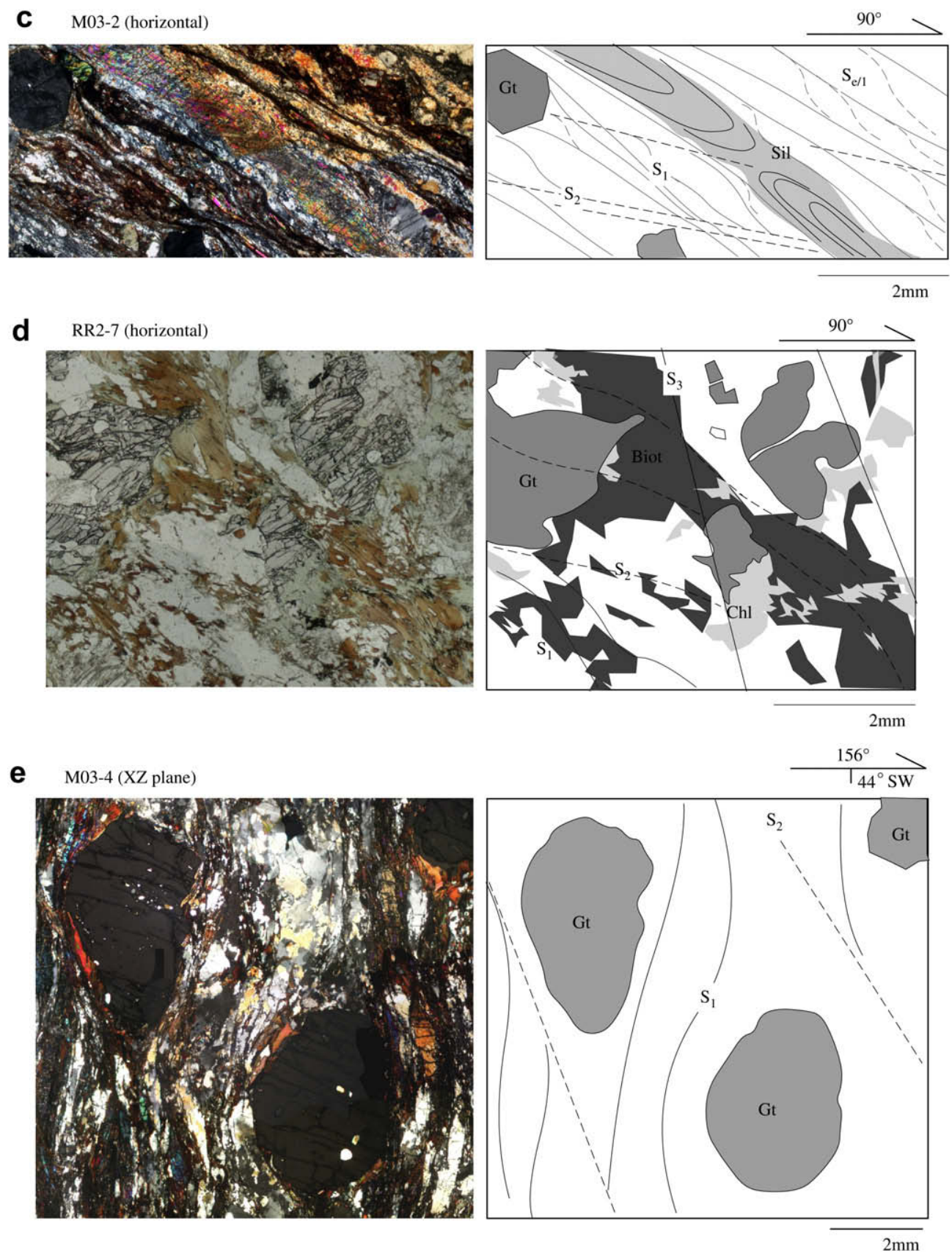

Fig. 3. (continued).

marked by quartz, feldspar, biotite, and muscovite fish (Figs. 3d and 4a). NE-SW striking, NW dipping $\left(40-50^{\circ}\right) \mathrm{S}$ fabrics of all mylonite samples showed ubiquitous anticlockwise asymmetries (or " $\mathrm{Z}$ ") across $\mathrm{F}_{3}$ fold limbs on both $\mathrm{XZ}$ and horizontal thin sections (Fig. 5c). The orientation of $C$ fabrics measured from mylonite samples along the Song Hong fault is parallel to the NW-SE strike of the RRSZ and close to vertical dipping, while the mylonite samples along the Song Chay fault also have RRSZ parallel WNW-ESE strike and are steeply dipping $\left(60-70^{\circ}\right)$ towards NE.

\section{Mineral assemblages and textures}

All gneiss samples contain quartz, feldspar, plagioclase, biotite and opaque minerals, such as ilmenite and magnetite. Garnet, sillimanite, muscovite and retrograde chlorite also occur in some samples. According to the mineral assemblages recorded along the
Bao Yan to Bao Ha and Yen Binh to Yen Bai transects, the general isograd pattern seems to reflect the geometry of the $F_{3}$ antiformal domes (Fig. 1b). This suggests that the core of the DNCV metamorphic dome experienced a higher metamorphic condition than both limbs. Two generations of garnet porphyroblast can be distinguished from core-rim relations as some samples contain inclusionfree rims with inclusion rich cores (Fig. 3e). The inclusions are composed mostly of quartz, mica and plagioclase and are generally fine grained than the matrix (Fig. $3 \mathrm{c}$ and e), but no inclusion trails were observed. All garnet porphyroblasts observed are truncated by matrix foliations suggesting that the matrix foliations formed later than the growth of garnet porphyroblasts during a long and complex deformation history. Garnet porphyroblasts with inclusion-free rims might have grown during matrix foliation development, but no timing criteria were available to demonstrate this. Most sillimanite bearing specimens contain these minerals in contact with biotite 
a

Bao Yen - Bao Ha Region

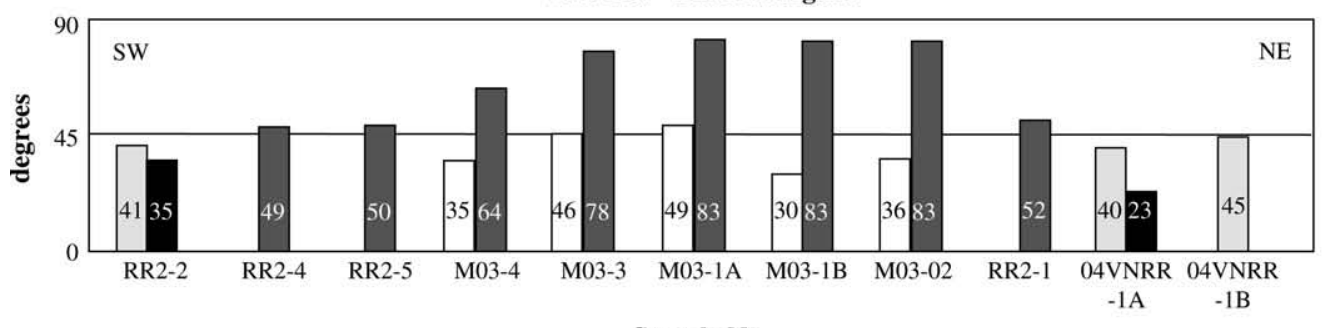

Sample No.
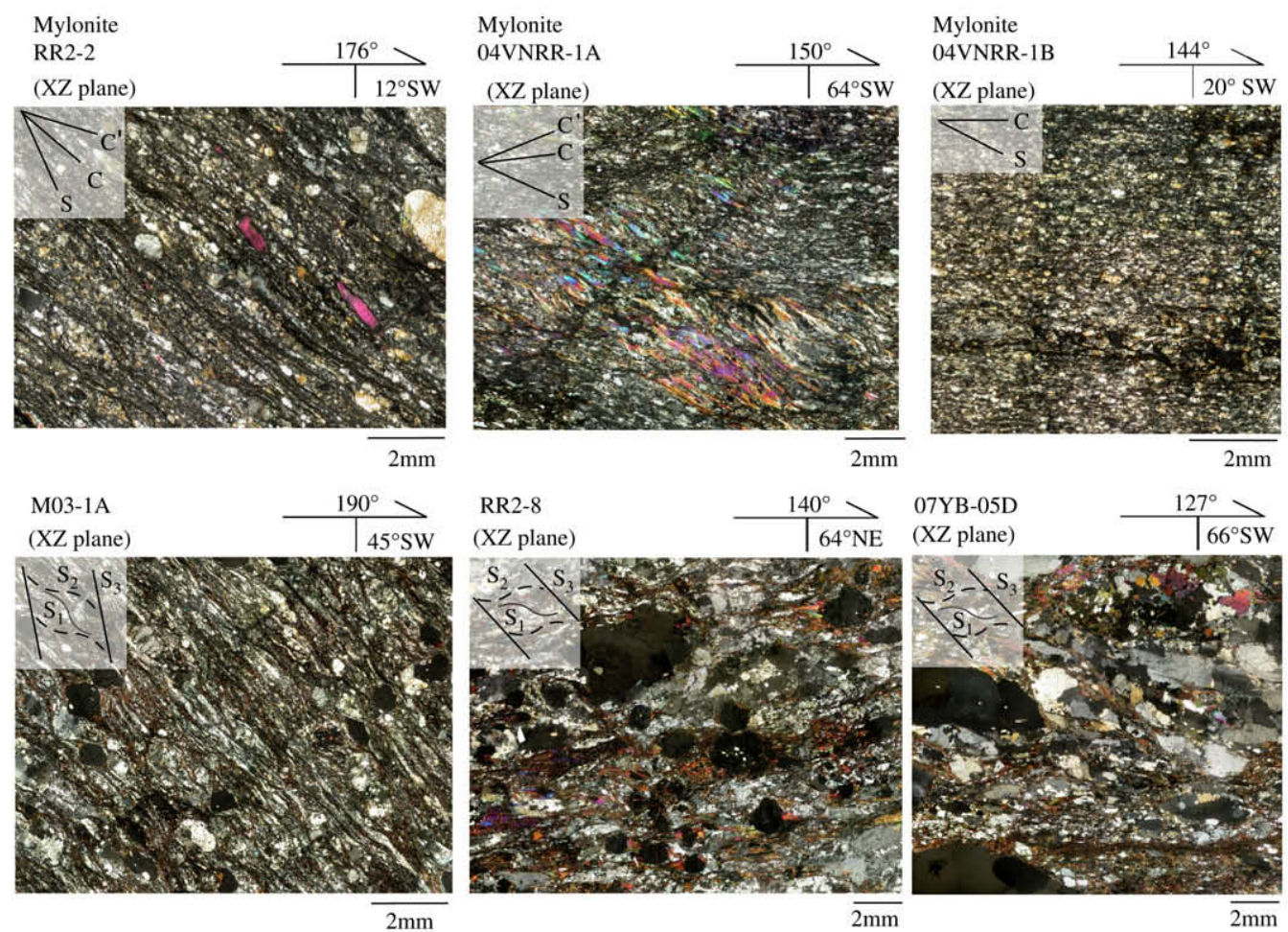

b
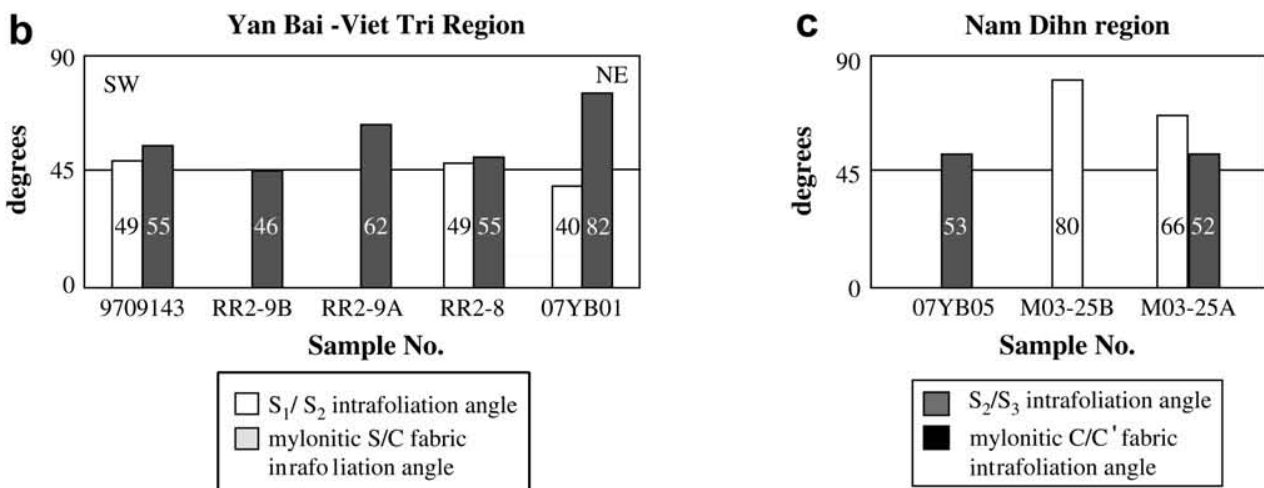

$\mathrm{S}_{2} / \mathrm{S}_{3}$ intrafoliation angle

mylonitic $\mathrm{C} / \mathrm{C}^{\prime}$ fabric

intrafoliation angle

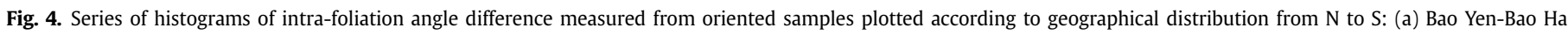

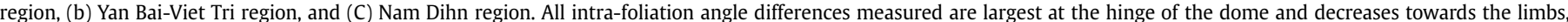

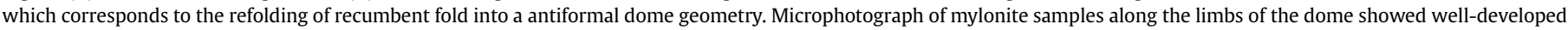
$\mathrm{S} / \mathrm{C}$ and $\mathrm{C}^{\prime}$ fabrics, overprinting fabrics of $\mathrm{S}_{1}, \mathrm{~S}_{2}$ and $\mathrm{S}_{3}$ can be seen for gneiss samples along the hinge of the dome. Please see text for further discussion.

and garnet porphyroblasts (Fig. 3a and e). By observing the mineral contact relationships, the reaction for sillimanite growth should be: garnet $\left(\mathrm{Fe}_{3} \mathrm{Al}_{2} \mathrm{Si}_{3} \mathrm{O}_{12}\right)+\mathrm{K}$-feldspar $\left(\mathrm{KAlSi}_{3} \mathrm{O}_{8}\right)+\mathrm{H}_{2} \mathrm{O}$ gives biotite $\left(\mathrm{KFe}_{3} \mathrm{AlSi}_{3} \mathrm{O}_{10}(\mathrm{OH})_{2}\right)+$ sillimanite $\left(\mathrm{Al}_{2} \mathrm{SiO}_{5}\right)+2$ quartz. Fibrolitic sillimanite parallel to $S_{1}$ and locally to $S_{2}$ and the folding pattern observed (Fig. 3a and c) suggests a similar timing of growth for sillimanite minerals during $\mathrm{F}_{2}$ with some growth possibly began after $F_{1}$ (Bell et al., 1986). The growth of pre to syn $D_{2}$ sillimanite in micaschists and gneiss suggests that the temperature during $\mathrm{F}_{2}$ folding reached the upper amphibolite facies.

\section{Kinematic interpretation}

Shear sense determinations along foliations in deformed and metamorphosed rocks are an important element of structural analysis, providing constraints on kinematic paths, and possibly 
a

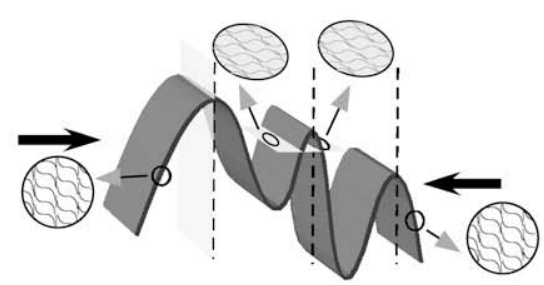

b

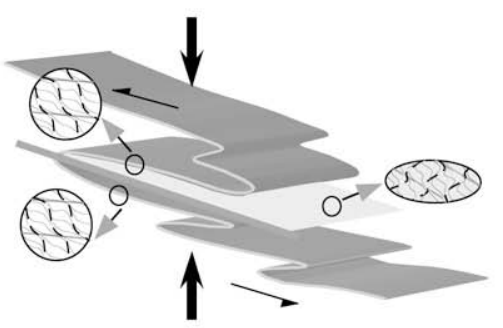

C

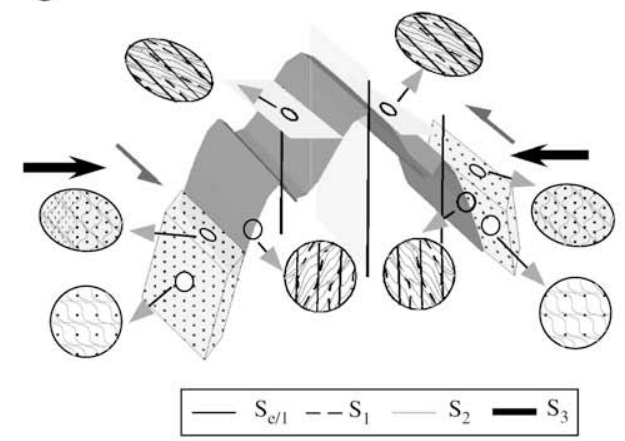

$D_{1}$ vertical cross section $(n=12)$

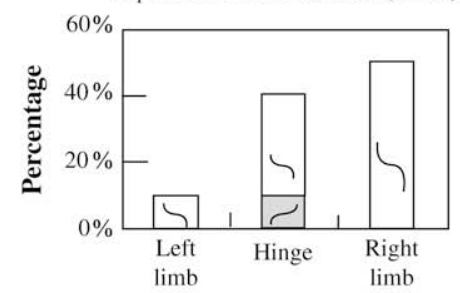

$D_{2}$ vertical cross section $(n=33)$

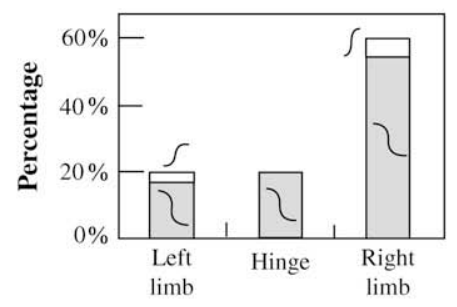

$D_{3}$ vertical cross section $(n=37)$

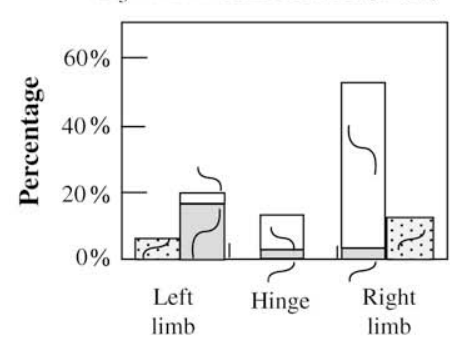

$D_{1}$ horizontal plane section $(n=16)$

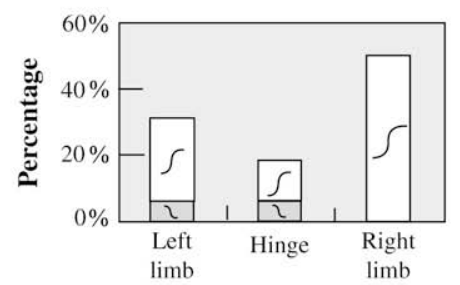

$D_{2}$ horizontal plane section $(n=28)$

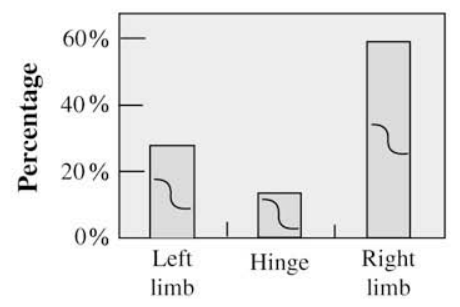

$\mathrm{D}_{3}$ horizontal plane section $(\mathrm{n}=25)$

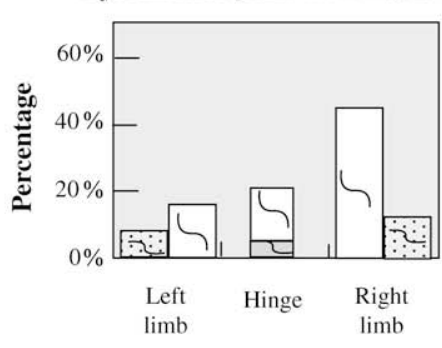

$\square \begin{aligned} & \text { Clockwise } \\ & \text { asymmetry }\end{aligned} \square \begin{aligned} & \text { Anticlockwise } \\ & \text { asymmetry }\end{aligned} \vdots \begin{aligned} & \text { Anticlockwise asymmetry } \\ & \text { for mylonite samples }\end{aligned}$

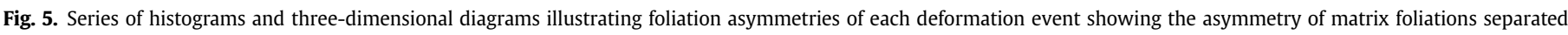

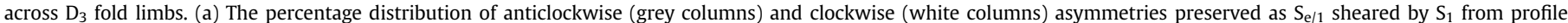

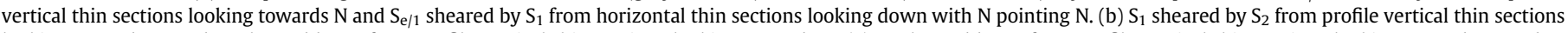

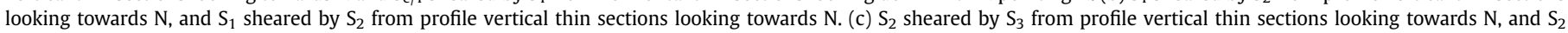
sheared by $\mathrm{S}_{3}$ from profile vertical thin sections looking towards $\mathrm{N}$.

metamorphic paths. For the past few decades, numerous meso to microscopic scale deformation structures have been shown to be reliable shear sense indicators (e.g., Hanmer and Passchier, 1991). Bell and Johnson (1992) pointed out that since deformation partitioning controls the development of new foliations in part by the rotation of older ones, the geometry developed must reflect the strain field. Therefore, to determine the local shear sense for a particular deformation event, one needs only to distinguish the curvature of earlier formed foliation into a later one on profile sections (that is from zones of low strain to zones of high strain).

Yeh (2007) showed that by detailed examination of the foliation asymmetries looking towards the same direction on profile thin sections of each foliation, one can determine the changes of kinematic conditions and the relative timing of folding events. Fig. 5 shows histogram plots of the asymmetry of each foliation curvatures separated according to $F_{3}$ fold limbs. Although all $S_{e / 1}$ fabrics observed preserve flat to steep curvature with a dominant clockwise asymmetry from both $\mathrm{F}_{3}$ limbs on both vertical profile thin sections (Fig. 5c) and horizontal thin sections (Fig. 5d). We cannot just interpret the strain field for $D_{1}$ is NE-SW compressional with dextral sense of shear. As pointed out by Goscombe and Trouw (1999), refolding of early foliations and associated sense of shear indicators is often not fully considered and can potentially lead to grossly incorrect tectonic interpretations. Thus, we only interpret the strain field for $D_{1}$ is $N W-S W$ compressional (Fig. 6a). All $S_{1}$ show a steep to flat curvature that is counter clockwise towards the flat $S_{2}$ on both vertical and horizontal thin sections (Fig. 5e and f).
With the exclusive top to NW and bottom to SE sense of shear and the NW-SE trending flat-lying sillimanite lineation, we conclude that the $F_{2}$ folds may have resulted from gravitational collapse with top to NW and bottom to SE simple shear generated by the horizontal midcrustal flow (Fig. 6b). Similar structures were also recognized by Jolivet et al. (2001), and were interpreted as evidence for the presence of a midcrustal sub-horizontal shear zone that joins the steep RRSZ.

Ramsay (1967), and Powell (1979) suggested that there is a systematic relation between fold geometry and fabrics initially orthogonal to the developing axial planar cleavage. This involves the foliation asymmetry reversing across the axial trace of a fold (Fig. 5a and b). In the case of the DNCV metamorphic complex, such asymmetry reversing was recorded for $\mathrm{D}_{3}$ (Fig. $5 \mathrm{~g}$ ). Subhorizontal $\mathrm{S}_{2}$ fabrics were rotated clockwise and counter clockwise into steep $S_{3}$ foliations at the right limbs and left limbs of $F_{3}$, respectively (Fig. 5g). Yet dominant clockwise asymmetries were recorded for $S_{2}$ on horizontal thin section (Fig. 5h). Based on the foliation asymmetry recorded from vertical thin sections, $F_{3}$ is the doming event of the DNCV metamorphic complex, during which the strain field must have remained compressional during $F_{3}$. Unlike the profile sections, only mylonite sample RR2-2 recorded anticlockwise asymmetry for $C$ bending into $C^{\prime}$ on horizontal thin section (Fig. $3 b$ ), the others all show NW-SE trending shallow $\mathrm{S}_{2}$ bending in to NNW-SSE trending upright $\mathrm{S}_{3}$ clockwise (Fig. $5 \mathrm{~h}$ ). If clockwise reactivation of $S_{2}$ occurred during $F_{3}$ rather than development of an $S_{3}$ axial plane cleavage (Bell, 1986), this would 

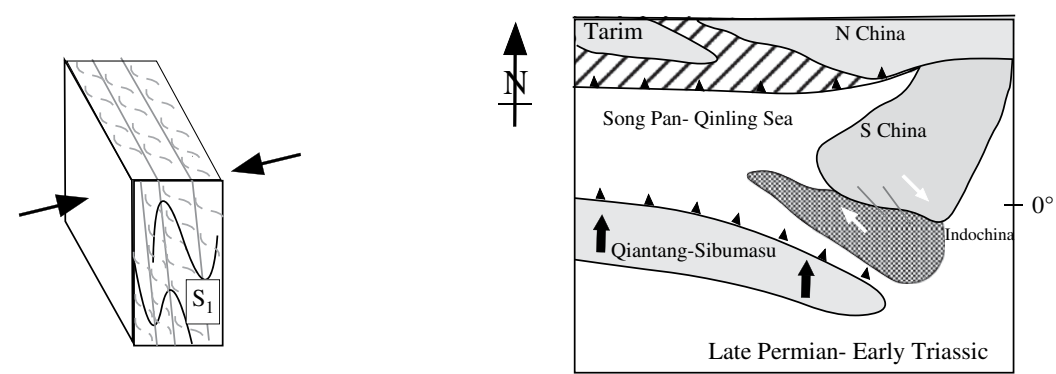

b $\mathrm{D}_{2}$ : Recumbent folding event due to pure shear at mid-crustal level suggested by syn-tectonic NW-SE trending sub-horizontal plunging fibrolitic sillimanite. Geochronology data indicates the prograde metamorphism might had lasted till 28 Ma since the Indosinian Orogeny.
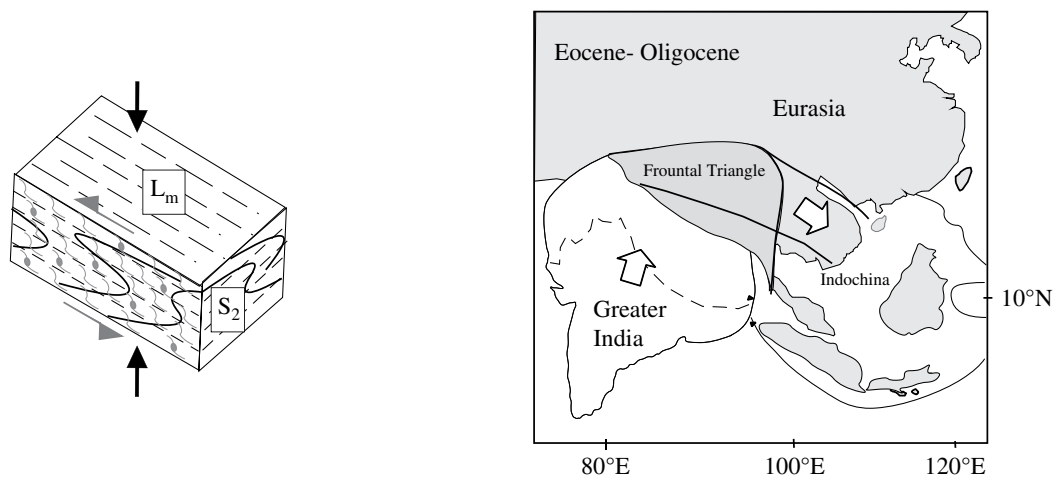

C $\mathrm{D}_{3}$ : Doming event. Left-lateral transpressional shearing along steep shear zones (retrograde metamorphism post India-Eurasia collision forming up-right N-S trending folds. The cooling history based on $\mathrm{Ar}-\mathrm{Ar}$ geochronology suggests the timing of $\mathrm{D}_{3}$ is post $28 \mathrm{Ma}$ )
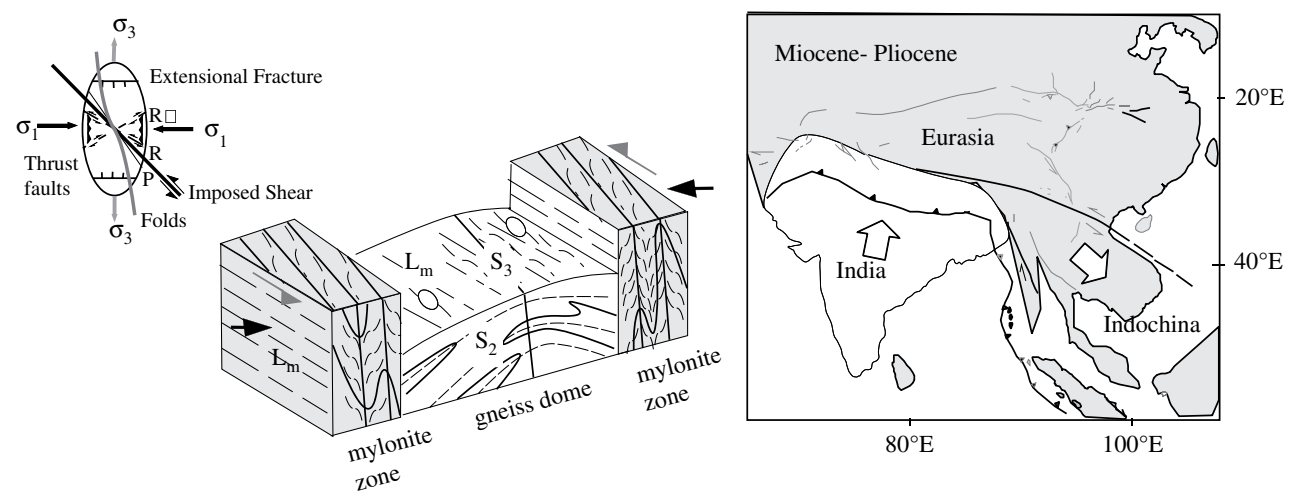

d $\mathrm{D}_{4}$ Extensional brittle deformation. Continuous left-lateral transverse activity of steep Song Hon and Song Chay strike-slip faults. (> $5 \mathrm{Ma}$ )
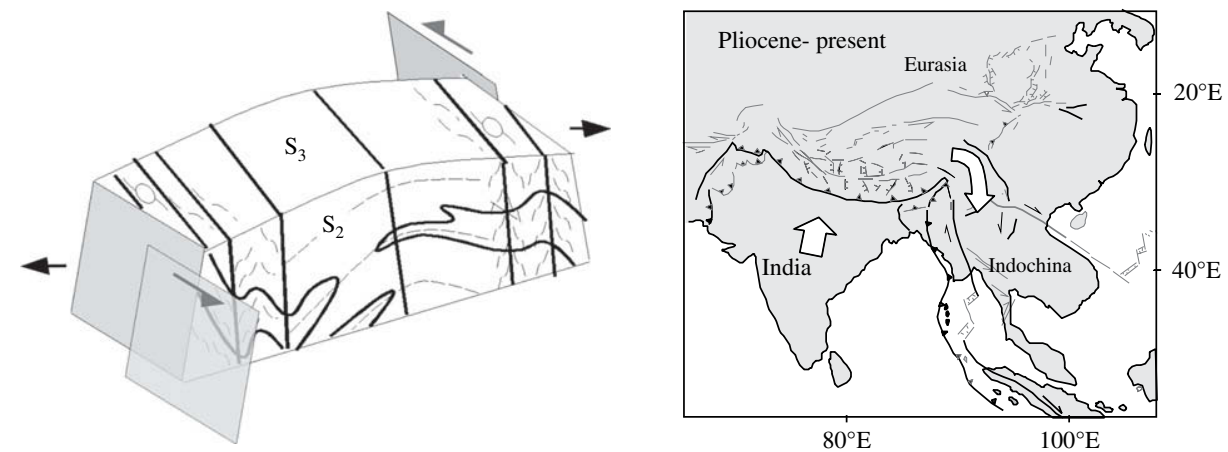

Fig. 6. Three-dimensional block diagrams illustrating proposed deformation history with tectonic settings of DNCV (modified from Carter et al., 2001 and Replumaz and Tapponnier, 2003) with north pointing to the top. 
have resulted in the primary anticlockwise $S_{1} / S_{2}$ differentiation asymmetry being switched to clockwise and produce the geometry shown in Fig. 6c.

\section{Geochronology correlation and reconstructed structural history}

\section{1. $D_{1}$}

The earliest structures observable at outcrop scale are the relics of tight isoclinal upright folds $\left(\mathrm{F}_{1}\right)$ with $\mathrm{NE}-\mathrm{SW}$ striking, variably dipping axial planes $\left(\mathrm{S}_{1}\right)$. 3D microstructural observations from orientated $\mathrm{XZ}, \mathrm{YZ}$, vertical and horizontal thin sections showed crenulated $S_{e / 1}$ as sub-horizontal to sub-vertical foliations with a dominant clockwise asymmetry looking towards N (Fig. 5a). This suggests that $\mathrm{D}_{1}$ was a horizontal shortening event (Figs. 5a and 6a). Since all garnet porphyroblasts have been truncated by the matrix foliations (Fig. 3a and c), metamorphism had reached garnet grade syn- or pre- $\mathrm{D}_{1}$ deformation. Isotopic dating provides constraints allowing broad correlation of deformation and/or metamorphism to be made. Compilation of published radiometric isotope age data for the DNCV shows that the garnet grade metamorphism probably extended to around $255 \mathrm{Ma}$ (Gilley et al., 2003). Based on the Sr-Nd characteristics of granitic rocks around the Song Ma ophiolite belt, Lan et al. (2000) reconstructed the crustal evolution of Northern Vietnam and suggested that the late Permian to early Triassic Dienbien Complex south of the Song Ma Suture was generated due to subduction-related processes during suturing between South China and Indochina (Indosinian Orogeny). With all rock members of the Song Ma ophiolite belt showing similar Ar-Ar ages (245 Ma; Lepvrier et al., 1997), Hutchison (1989a,b) suggested that this early Triassic suturing event had caused regional metamorphism and magmatism and interpreted this event to be the early phase of the Indosinian orogeny. With the similar age span for the regional metamorphism and the same NW-SE trend of $\mathrm{D}_{1}$ structures with the Song Ma suture, we suggest that the $\mathrm{D}_{1}$ structures were the result of the amalgamation between the South China and Indochina during the Triassic Indosinian Orogeny (Fig. 6a).

\section{2. $D_{2}$}

$D_{2}$ is the most dominant deformation and metamorphic event of the DNCV. It refolded $D_{1}$ folds to sub-horizontal folds $\left(F_{2}\right)$ with sub-horizontal axial planes $\left(S_{2}\right)$, which overprinted $S_{1}$ with a differentiated crenulation cleavage $S_{2}$ containing an NW-SE trending sub-horizontal sillimanite mineral stretching lineation (Fig. 3a). Sub-vertical sigmoidal $\mathrm{S}_{1}$ foliations defined by elongated quartz, biotite, and sillimanite minerals are crenulated with an anticlockwise asymmetry looking $\mathrm{N}$ into $\mathrm{S}_{2}$ (Figs. 3 and $5 \mathrm{~b}$ ). This suggests that $\mathrm{D}_{2}$ formed by vertical shortening with top to $\mathrm{W}, \mathrm{NW}$ shear that rotated $F_{1}$ into recumbent folds or sheath folds at midcrustal levels. Sillimanite parallel to $S_{1}$ and $S_{2}$ (Fig. 3) suggests that minerals grew during $\mathrm{D}_{2}$. As indicated by garnet composition zoning (Nam et al., 1998) and sillimanite wrapping garnet porphyroblasts (Fig. 3a), prograde metamorphism occurred from $D_{1}$ to $D_{2}$ at under the midcrustal levels. This implies that the regional metamorphism continued since the Triassic Indosinian Orogeny onward.

$\mathrm{D}_{2}$ was the major structural and metamorphism event with foliations having exclusive top to $\mathrm{W}-\mathrm{NW}$ sense of shear. Based on Gilley et al. (2003), the $\mathrm{Pb} / \mathrm{Th} / \mathrm{U}$ ages obtained from monazite extended from 255 to $21 \mathrm{Ma}$. All monazite inclusions within garnet porphyroblasts exhibit $\mathrm{Pb} / \mathrm{Th} / \mathrm{U}$ ages older than $43 \mathrm{Ma}$. This would suggest that garnet stopped growth even later than $43 \mathrm{Ma}$. By compiling $\mathrm{Ar}-\mathrm{Ar}, \mathrm{K}-\mathrm{Ar}$ and $\mathrm{Pb}-\mathrm{U}$ age data according to the closing temperature of various mineral reported by previous researchers (Harrison et al., 1996; Nam, 1998; Wang et al., 1998, 2000; Roger et al., 2000; Leloup et al., 2001a,b; Nam et al., 2001, 2002; Gilley et al., 2003; Liang et al., 2007), Fig. 7 clearly shows that the P-T conditions throughout the entire DNCV remained above $450{ }^{\circ} \mathrm{C}$ till $28 \mathrm{Ma}$, and no rapid cooling had occurred prior to $28 \mathrm{Ma}$. Based on the geochronology, microstructural constrains, we suggest that the $\mathrm{D}_{2}$ had lasted till $28 \mathrm{Ma}$ after the Triassic Indosinian orogeny.

\section{3. $D_{3}$}

The youngest ductile deformation event observed along the DNCV metamorphic complex, $\mathrm{D}_{3}$, is a doming event. This formed

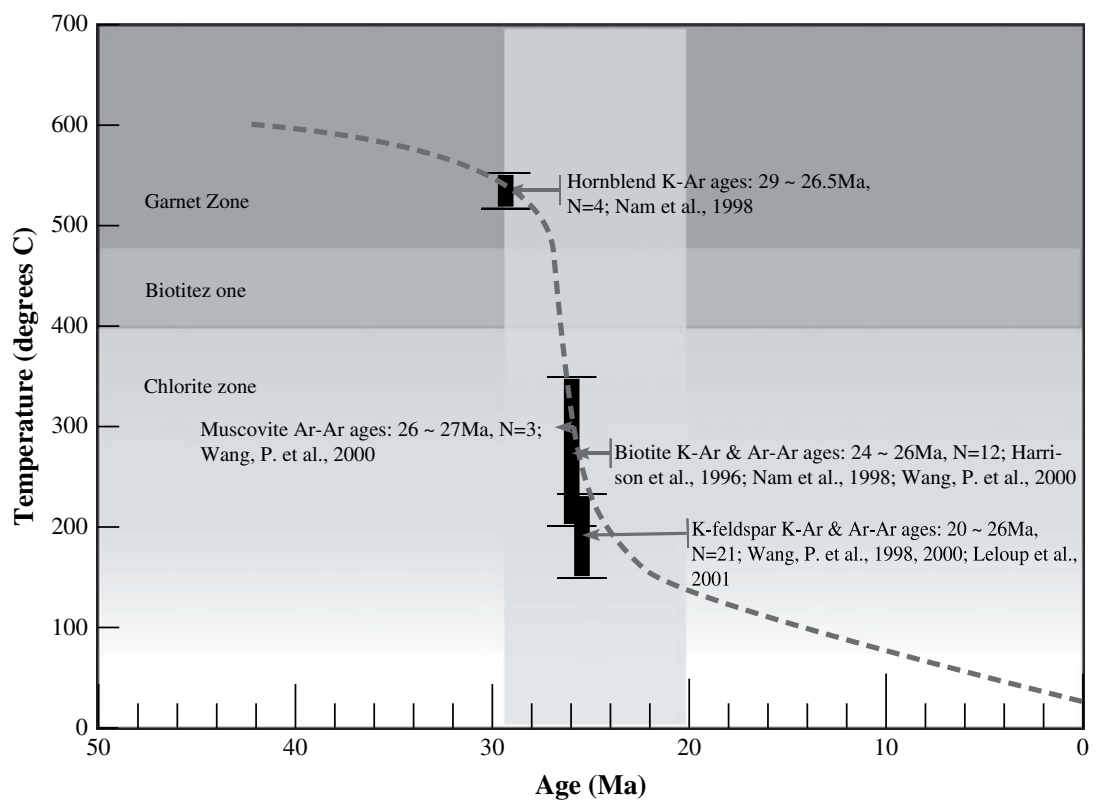

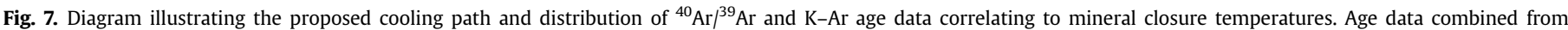

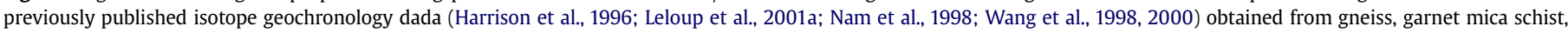

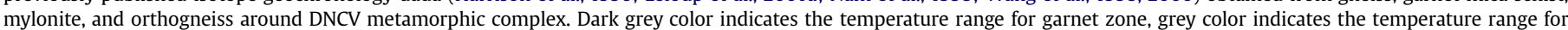

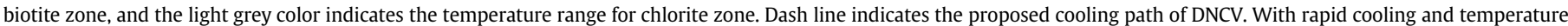
range at the chlorite zone, we propose that the $\mathrm{D}_{3}$ had begun after $28 \mathrm{Ma}$. 
open upright folds $\left(\mathrm{F}_{3}\right)$ with NW-SE striking (around $310-330^{\circ}$ ), with vertically dipping (around $88^{\circ}$ to $\mathrm{NE}$ ) axial planes $\left(\mathrm{S}_{3}\right)$. The pattern of generally increasing metamorphic grade of quartz+ feldspar + plagioclase + biotite towards deeper structural levels in the center of the complex (quartz + feldspar + plagioclase + biotite + garnet \pm sillimanite) suggests that the major period of metamorphism occurred prior to $\mathrm{D}_{3}$ doming. Subhedral biotite and a few chlorite grains parallel to $S_{3}$ suggest a retrograde metamorphic event during $\mathrm{D}_{3}$, Nam et al. (1998) also noted a chlorite-grade retrogression stage after garnet growth. Muscovite, plagioclase, quartz and biotite commonly occur in cracks in garnet porphyroblasts. Anczkiewicz et al. (2007) ruled out the possibility that the pre-existing flat fabrics were passively rotated to their present upright position by folding or footwall dragging due to the lack of kinematic switch across the folds. They suggested that the DNCV antiform uplifted and exhumed the pre-existing sub-horizontal midcrustal gneisses within a left-lateral transtensional crustal corridor. Based on low temperature (biotite growing into chlorite) $\mathrm{S}_{3}$ fabrics (Fig. 3d) and exclusive sinistral muscovite fish preserved within mylonite zones along both limbs of the DNCV antiform, we suggest that the DNCV antiform should have formed by refolding of $D_{2}$ recumbent folds under left-lateral transpressional condition post-28 Ma, as the metamorphic condition had began to show rapid cooling (Fig. 6c). The biotite and K-feldspar mineral separates from mylonite next to Bao Yen (RR15) yield $\mathrm{Ar}-\mathrm{Ar}$ age of $21.2 \pm 0.2 \mathrm{Ma}$ and $21.5 \pm 0.2 \mathrm{Ma}$, respectively (Wang et al., 1998 ) indicating that the left-lateral transpressional movement had reached a peak by this time.

\section{4. $D_{4}$}

Brittle deformations structures, such as joint, left-lateral faults (striking NW-SE) in outcrop scale and fractures within mineral grains under the microscope, are younger than folding events as they all cross-cut the matrix foliations (Fig. 2). This suggests that the DNCV metamorphic complex was uplifted through the brittleductile transition zone during/or after $\mathrm{D}_{3}$. With left-lateral faulting $\left(D_{4}\right)$ younger than the ductile deformation $\left(D_{3}\right)$, we interpret that $\mathrm{D}_{4}$ to have occurred during left-lateral movement along the RRSZ (Fig. 1c). Due to the lack of suitable dating material for $D_{4}$, it is difficult to determine the upper bound of this event. However, since no fault penetrated the $5.5 \mathrm{Ma}$ unconformity according to seismic profiles and exploration wells in the Tonkin Gulf, Rangin et al. (1995) concluded that there was little motion of the RRSZ post5.5 Ma. Therefore, we suggest that $\mathrm{D}_{4}$ might have lasted till $5 \mathrm{Ma}$.

\section{Tectonic interpretation and discussion}

Molnar and Tapponnier (1975) and Tapponnier et al. (1982) originally proposed the indentation-extrusion model as a tectonic mechanism to explain large-scale strike-slip faults in Asia. The indentation model treats the continental lithosphere as a rigid medium with most deformation concentrated along major strikeslip faults and little or no deformation between them. England and McKenzie (1982) and Burchfiel et al. (1989) proposed an alternate theory that the continental lithosphere is viscous and deformations are more distributed over hundreds to thousands of kilometers.

\subsection{Significance of the horizontal foliation}

Generally, sub-vertical cleavages with sub-horizontal stretching lineations and sub-vertical folds are associated with strike-slip tectonics. However, our field data from the DNCV shows that subhorizontal structures might also played an important role in the metamorphic and structural evolution. The presence of a flat foliation along with shallowly plunging NW-SE trending sillimanite mineral stretching lineations within the DNCV had long been known (e.g., Tapponnier et al., 1990; Leloup et al., 2001a; Jolivet et al., 2001). Leloup et al. (2001a) noted that it formed the main difference between the DNCV and other metamorphic complexes of the RRSZ and identified the flatness of the foliation as result from vertical flattening during left-lateral transtensional movement along the RRSZ. Jolivet et al. (2001) and Searle (2006, 2007) suggested that strike-slip faults do not necessarily root deeply and, therefore, do not have to cut through the entire lithosphere. The DNCV might have been deformed at depth along a horizontal shear zone prior to exhumation through a steeper one. This corresponds to our observations as well. The presence of a sub-horizontal fold structure, $F_{2}$, which was not taken into account in previous studies, provides good evidence that these syn-tectonic sillimanite bearing flat foliations $\left(\mathrm{S}_{2}\right)$ formed at midcrustal levels during regional metamorphism.

Leloup et al. $(1995,1999)$ and Scharer et al. (1990) had proposed shear heating alone as a sufficient heat source for metamorphism for the metamorphic complexes along the RRSZ. Similar regional metamorphic conditions and fabrics are also noted outside of the RRSZ, such as the Truong Son belt (Lepvrier et al., 1997) and Song Chay dome (Jolivet et al., 2001). Contradicting geochronologic data from monazite inclusions in garnet porphyroblasts (Gilley et al., 2003) show that high temperatures were maintained at midcrust level for about 10 My between the Oligocene and the Miocene. This suggests that $D_{2}$ was long lasting, and that the dominant heat source generating amphibolite-facies metamorphism at the midcrust level was loading of the crust rather than shear heating. Burchfiel (2004) suggested that the northward indentation of India into Eurasia and gradients in gravitational potential energy from the central high Tibetan plateau were the main driving mechanism for crustal flow/rotation in this region. By modeling the effects of midcrustal channel flow in a thermal-mechanical model (HT1), Jamieson et al. (2004) successfully established several compatible features with the Himalayan-Tibetan system. Radioactive selfheating and rheological weakening of thickened crust can lead to the formation of a hot, low-viscosity midcrustal channel and a broad plateau, which stores the gravitational potential energy (Jamieson et al., 2004). As response to the topographically induced pressure, horizontal channel material at midcrustal level flows outward from the plateau (Royden et al., 1997; Clark and Royden, 2000; Jamieson et al., 2004).

\subsection{Compressional crenulation cleavage (CCC) vs. extensional crenulation cleavage (ECC)}

Foliation anisotropy is often observed in metamorphic rocks within shear zones, and classically interpreted as shear bands (White, 1979), C'-bands (Ponce De Leon and Choukroune, 1980) or extensional crenulation cleavage (Platt, 1979, 1984; Platt and Vissers, 1980). These fabrics along with asymmetric boudinage, normal kink-bands (Cobbold et al., 1971; Cosgrove, 1976) were generally interpreted as a result of extension along the older anisotropy or shortening normal to the anisotropy. Their 'sense of shear' and geometrical relations are widely used to describe the kinematics and tectonic settings of the deformation (Berthe et al., 1979; Platt and Vissers, 1980; Simpson and Schmid, 1983; Lister and Snoke, 1984; Behrmann, 1987; Cosgrove, 2007). As Passchier and Trouw (1996) pointed out, shear bands may resemble the compressional crenulation cleavage (CCC) but develop by extension (extensional crenulation cleavages - ECC) of the older foliation rather than by shortening, and the main differences between CCC and ECC are the intra-foliation angle. Generally, the intra-foliation angle between CCC and pre-existing foliation ranges between $45^{\circ}$ and $90^{\circ}$, while for ECC the angle to pre-existing foliation is less than $45^{\circ}$. Fig. 4 shows the intra-foliation angle measured between foliations from 
stereonet across the DNCV metamorphic complex in relevant geographical locations. Other than samples from Nam Dihn, most $\mathrm{S}_{1} / \mathrm{S}_{2}$ intra-foliation angles range between 53 and $30^{\circ}$ with an average of $47^{\circ}$. Other than mylonite samples RR2-2, 04VNRR1a and 04VNRR1b, all $S_{2} / S_{3}$ intra-foliation angles are higher than $45^{\circ}$ (range between 46 and $83^{\circ}$; Fig. $4 \mathrm{~b}$ ) with an average of $62^{\circ}$, suggesting that $S_{3}$ in gneiss samples are CCC formed under compressional condition and developed at high angle to the bulk shortening direction, which is generally E-W (Fig. 6c). Samples RR2-2 and 04VNRR1a are mylonites and both intra-foliation angles and foliation altitudes showed classical $S / C$ and $C^{\prime}$ foliations (Fig. $3 b$ ). With evidences such as: the $S_{1} / S_{2}$ intra-foliation angles' decreases towards the limbs of $D_{3}$ dome (Fig. 4a), and much higher $S_{1} / S_{2}$ intra-foliation angles recorded from region less effected by $D_{3}$, we interpret that the $\mathrm{S}_{2}$ foliations are also CCC and the bulk shortening direction would be gravitational (Fig. 6b). Unlike previous authors' interpretation (Leloup et al., 2001a), these oblique foliations observed from the DNCV metamorphic complex were not developed synchronously but were developed through multiple deformation episodes as demonstrated in this study.

\section{Conclusion}

Metamorphic rocks along the DNCV complex in Vietnam have been previously thought to be formed by shearing along the Ailao Shan-Red River Shear Zone during left-lateral shear and continental escape tectonics (Tapponnier et al., 1982, 1990; Leloup et al., 1995, 2001). However, a reassessment of the structural evolution of the DNCV metamorphic complex from the Red River Shear Zone in Vietnam shows that these gneisses were formed during earlier tectonic and metamorphic episodes unrelated to strike-slip shearing (Searle, 2006, 2007). Fabrics were superimposed after metamorphism and after granite formation. Key observations are: (1) the DNCV metamorphic complex in Northern Vietnam records three phases of folding followed by brittle deformation events lasting from the Triassic to the Tertiary. (2) $D_{1}$ is preserved as NW-SE striking upright folds formed during the Triassic Indosinian orogeny as South China block collided with the Indochina block. (3) The large-scale horizontal $\mathrm{D}_{2}$ folds with a top to N/NW, bottom to $\mathrm{S} / \mathrm{SW}$, sense of shear, and fold axial planes developed in sillimanite-grade conditions suggest that the DNCV metamorphic complex was first deformed at midcrustal depths along a horizontal shear zone (Jolivet et al., 2001; Searle, 2006). (4) Based on Ar-Ar geochronological data, rapid cooling occurred after $28 \mathrm{Ma}$ in the DNCV, suggesting that the left-lateral transpressional $\mathrm{D}_{3}$ doming event uplifted the DNCV. (5) Steep mylonite zones and brittle faults were developed along the steep Song Hong and Song Chay faults bounding the DNCV during continuous left-lateral movement of the RRSZ. The presence of this midcrustal horizontal shear zone provides an alternative interpretation to that of lithospheric scale strike-slip faults (such as the RRSZ). Such faults need not root from the mantle.

\section{Acknowledgements}

We especially thank Drs. Tran Trong Hoa and Dinh Van Toan of the National Center for Natural Sciences and Technology (NCNST), Vietnam for their kind arrangement and administration of the field work. Te-Hsien Lin (National Taiwan University) and Yo-Jia Lin (National Taiwan Normal University) are thanked for their generous assistance in the field and for thin section making. T. Bell, L. Jolivet, B. Burchfiel, Marcos Egydio Silva are thanked for useful comments and suggestions on an early version of this manuscript. $\mathrm{R}$. Wintsch is thanked for tremendous helpful and enlighten section interlinking geochronology and metamorphic petrology of this region. Mike Searle is thanked for extremely helpful discussion in the field and English revision of this paper. We wish to acknowledge the support of the National Science Council of Taiwan under grant NSC91-2116-M-003-010, and facilities provided by the National Taiwan Normal University, Taipei, Taiwan.

\section{References}

Anczkiewicz, R., Viola, G., Müntener, O., Thirlwall, M.F., Villa, I.M., Nguyen, Quoc Quong, 2007. Structure and shearing conditions in the Day Nui Con Voi massif: implications for the evolution of the Red River shear zone in northern Vietnam. Tectonics 26, doi:10.1029/2006TC001972.

Allen, C.R., Gillepsie, A.R., Yuan, Han, Sieh, K.E., Zhang, Buchun, Zhu, C., 1984. Red River and associated faults, Yunnan Province, China: Quaternary geology slip rates, and seismic hazard. Geological Society of America Bulletin 95, 686-700.

Bell, T.H., Rubenach, M., 1983. Sequential porphyroblast growth and crenulation cleavage development during progressive deformation in tectonics. Tectonophysics 92 (1-3), 171-194.

Bell, T.H., 1986. Foliation development and refraction in metamorphic rocks: reactivation of earlier foliations and de-crenulation due to shifting patterns of deformation partitioning. Journal of Metamorphic Geology 4 (4), 421-444.

Bell, T.H., Fleming, P.D., Rubenach, M., 1986. Porphyroblast nucleation, growth and dissolution in regional metamorphic rocks as a function of deformation partitioning during foliation development. Journal of Metamorphic Geology 4, 37-67.

Bell, T.H., Johnson, S.E., 1992. Shear sense: a new approach that resolves conflicts between criteria in metamorphic rocks. Journal of Metamorphic Geology 10 99-124.

Bell, T.H., Hickey, K.A., Upton, J.G., 1998. Distinguishing and correlating multiple phases of metamorphism across a multiply deformed region using the axes of spiral, staircase and sigmoidal inclusion trails in garnet. Journal of Metamorphic Geology 16, 767-794.

Behrmann, J.H., 1987. A precautionary note on shear bands as kinematic indicators. Journal of Structural Geology 9, 659-666.

Berthe, D., Choukroune, P., Jegouzo, P., 1979. Orthogneiss mylonite and non-coaxial deformation of granites: the example of the South Armoricain shear zone. Journal of Structural Geology 1, 31-42.

Burchfiel, B.C., Deng, Q., Molnar, P., Royden, L., Wang, Y., Zhang, P., Zhang, W., 1989. Intracrustal detachment within zones of continental deformation. Geology 17, 748-752.

Burchfiel, B.C., Wang, E., 2003. Northwest-trending, middle Cenozoic, left-lateral faults in southern Yunnan, China, and their tectonic significance. Journal of Structural Geology 25, 781-792.

Burchfiel, B.C., 2004. New technology: new geological challenges. GSA Today 14 (2), 4-104.

Carter, A., Roques, D., Bristow, C., Kinny, P., 2001. Understanding Mesozoic accretion in Southeast Asia. Significance of Triassic thermotectonism (Indosinian Orogeny) in Vietnam. Geology 29, 211-214.

Chung, S.L., Lee, T.Y., Lo, C.H., Wang, P.L., Chen, C.Y., Nguyen, T.Y., Tran, T.H., Wu, G.Y. 1997. Intraplate extension prior to continental extrusion along the Ailao ShanRed River shear zone. Geology 25, 311-314.

Clark, M.K., Royden, L.H., 2000. Topographic ooze: building the eastern margin of Tibet by lower crustal flow. Geology 28, 703-706.

Cobbold, P.R., Cosgrove, J.W., Summers, J.M., 1971. Development of internal structures in deformed anisotropic rocks. Tectonophysics 12, 23-53.

Cong, D.C., Feigl, K.L., 1999. Geodetic measurement of horizontal strain across the Red River fault near Thac Ba, Vietnam, 1963-1994. Journal of Geodesy 73, 298-310.

Cosgrove, J.W., 1976. The formation of crenulation cleavage. Journal of the Geological Society, London 262, 153-176.

Cosgrove, J.W., 2007. The use of shear zones and related structures as kinematic indicators: a review. In: Geological Society of London, Special Publications, 272 pp. 59-74.

Davis, B.K., Forde, A., 1994. Regional slaty cleavage formation and fold axis rotation by re-use and reactivation of pre-existing foliations: the Fiery Creek Slate Complex, North Queensland. Tectonophysics 230, 161-179.

England, P.C., McKenzie, D.P., 1982. A thin viscous sheet model for continental deformation. Geophysical Journal of the Royal Astronomical Society 70, 295-321.

Feigl, K.L., Cong, D.C., Becker, M., Tran, D.T., Newman, K., Nguyen, Q.X., 2003 Insignificant horizontal strain across the Red River fault Near Thac ba, Vietnam from GPS measurements 1994-2000. Abstracts of EGS-AGU-EUG Joint Assembly, Nice, France.

Department of Geology and Minerals of Vietnam, 1983. Geological and Mineral Resources map of Viet Nam 1:500,000. Department of Geology and Minerals of Viet Nam, Ha Noi.

Gilley, L.D., Harrison, T.M., Leloup, P.H., Ryerson, F.J., Lovera, O.M., Wang, J.H., 2003. Direct dating of left-lateral deformation along the Red River shear zone, China and Vietnam. Journal of Geophysical Research 108 (B2), 2127, doi:10.1029/ 2001JB001726.

Goscombe, B., Trouw, R., 1999. The geometry of folded tectonic shear sense. Journal of Structural Geology 21, 123-127.

Hall, R., 1996. Reconstructing Cenozoic SE Asia. In: Hall, R., Blundell, D.J. (Eds.), Tectonic Evolution of SE Asia. Geological Society of London, Special Publication, vol. 106, pp. 153-184.

Hanmer, S.K., Passchier, C., 1991. Shear-sense Indicators: a Review, Geological Survey of Canada Paper, pp. 90-17. 
Harrison, T.M., Chen, W., Leloup, P.H., Ryerson, F.J., Tapponnier, P., 1992. An Early Miocene transition in deformation regime within the Red River Fault zone, Yunnan, and its significance for Indo-Asian tectonics. Journal of Geophysical Research 97, 7159-7182.

Harrison, T.M., Leloup, P.H., Ryerson, F.J., Tapponnier, P., Lacassin, R., Chen, W., 1996 Diachronous initiation of transtension along the Ailao Shan-Red River shea zone, Yunnan and Vietnam. In: Yin, A., Harrison, T.M. (Eds.), The Tectonic Evolution of Asia. Cambridge University Press, pp. 110-137, pp. 208-226.

Hobbs, B.E., Means, W.D., Williams, P.F., 1976. An Outline of Structural Geology. Wiley \& Sons, New York, pp. 409-416.

Hutchison, C.S., 1989a. Displaced terranes of the Southwest Pacific. In: BenAvraham, Z. (Ed.), The Evolution of the Pacific Ocean Margins. Oxford University Press, pp. 161-175.

Hutchison, C.S., 1989b. Geological Evolution of Southeast Asia. Clarendon, Oxford $368 \mathrm{pp}$.

Jamieson, R.A., Beaumont, C., Medvedev, S., Nguyen, M.H., 2004. Crustal channe flows: 2. Numerical models with implications for metamorphism in the Himalayan-Tibetan orogen. Journal of Geophysical Research - Solid Earth 109 (B6) No. B06407.

Johnson, S.E., Vernon, R.H., 1995. Inferring the timing of porphyroblast growth in the absence of continuity between inclusion trails and matrix foliations: can it be reliably done? Journal of Structural Geology 17 (8), 1203-1206.

Jolivet, L., Maluski, H., Beyssac, O., Goffe, B., Lepvrier, C., Thi, P.T., Vuong, N.V., 1999. Oligocene-Miocene Bu Khang extensional gneiss dome in Vietnam: geodynamic implications. Geology 27, 67-70

Jolivet, L., Beyssac, O., Goffe, B., Avigad, D., Lepvrier, C., Maluski, H., Thang, T.T., 2001. Oligo-Miocene midcrustal subhorizontal shear zone in Indochina. Tectonics 20 46-57.

Lacassin, R., Leloup, P.H., Tapponnier, P., 1993. Bounds on strain in large Tertiary shear zones of SE Asia from boudinage restoration. Journal of Structural Geology 15, 677-692.

Lan, C., Chung, S., Shen, J., Lo, C.H., Wang, P., Hoa, T., Thanh, H., Mertzman, A., 2000 Geochemical and $\mathrm{Sr}-\mathrm{Nd}$ isotopic characteristics of granitic rocks from northern Vietnam. Journal of Asian Earth Sciences 18, 267-280.

Leloup, P.H., Kienast, J.R., 1993. High-temperature metamorphism in a major strikeslip shear zone: the Ailao Shan-Red River, People's Republic of China. Earth Planetary Science Letter 118, 213-234.

Leloup, P.H., Lacassin, R., Tapponnier, P., Zhong, D., Liu, X., Zhang, L., Ji, S., Trinh, P.T., 1995. The Ailao Shan-Red River shear zone (Yunnan, China), Tertiary transform boundary of Indochina. Tectonophysics 251, 3-84.

Leloup, P.H., Ricard, Y., Battaglia, J., Lacassin, R, 1999. Shear heating in continenta strike-slip shear zones: numerical modeling and case studies. Geophysical Journal International 136, 19-40.

Leloup, $\mathrm{PH}$, Arnaud, $\mathrm{N}$, Lacassin, $\mathrm{R}$, Kienast, J R, Harrison, TM, Trinh, PT Replumaz, A., Tapponnier, P., 2001a. New constraints on the structure, thermochronology and timing of the Ailao Shan-Red River shear zone, SE Asia Journal of Geophysical Research 106, 6683-6732.

Leloup, P.H. Lacassin, R., Tapponnier, P., Harrison, T.M., 2001b. Comment on “Onset timing of left-lateral movement along the Ailao Shan-Red river shear zone: ${ }^{40} \mathrm{Ar} /{ }^{39} \mathrm{Ar}$ dating constraint from the Nam Dinh area, northeastern Vietnam" by Wang, et al., 2000. Journal of Asian Earth Sciences 18, 281-292. Journal of Asian Earth Sciences 20, 95-99.

Leloup, P.H., Tapponnier, P., Lacassin, R., Searle, M.P., 2007. Discussion on the role of the Red River shear zone, Yunnan and Vietnam, in the continental extrusion of SE Asia. Journal of the Geological Society, London 164 (6), 1253-1260.

Lepvrier, C., Maluski, H., Vuong, N.V., Roques, D., Axente, V., Rangin, C., 1997. Indosinian NW-trending shear zones within the Truong Son complex ${ }^{40} \mathrm{Ar}-{ }^{39} \mathrm{Ar}$ Triassic ages and Cretaceous to Cenozoic overprints. Tectonophysics 283 105-127.

Liang, H.Y., Campbell, I.H., Allen, C.M., Sun, W.D., Yu, H.X., Xie, Y.W., Zhang, Y.Q. 2007. The age of the potassic alkaline igneous rocks along the Ailao Shan-Red River Shear Zone: implications for the onset age of left-lateral shearing. Journal of Geology 115, 231-242.

Lister, G.S., Snoke, A.W., 1984. S-C mylonites. Journal of Structural Geology 6, 617-638

Maluski, H., Lepvrier, C., Rouqyes, D., Nguyen, V., Phan, V.V., Rangin, C., 1995. ${ }^{40} \mathrm{Ar}-{ }^{39} \mathrm{Ar}$ ages in the Da Nang-Dai Loc plutono-metamorphic complex (Central Viet Nam) overprinting process of Cenozoic over Indosinian thermotectonic episodes. Workshop Cenozoic Evolution of the Indochina Peninsula, Hanoi-Do Son, Viet Nam, 65 pp.

Maluski, H., Lepvrier, C., Jolivet, L., Carter, A., Roques, D., Beyssac, O., Tang, T.T., Thang, N.D., Avigad, D., 2001. Ar-Ar and fission-track ages in the Song Chay Massif: Early Triassic and Cenozoic tectonics in northern Vietnam. Journal of Asian Earth Sciences 25 (19), 233-248.

Molnar, P., Tapponnier, P., 1975. Cenozoic tectonics of Asia: effects of a continental collision. Science $189,419-426$

Nam, T.N., 1998. Thermotectonic events from early Proterozoic to Miocene in the Indochina craton: implication of $\mathrm{K}-\mathrm{Ar}$ ages Vietnam. Journal of Asian Earth Sciences $16,475-484$.

Nam, T.N., Toriumi, M., Itaya, T., 1998. P-T-t paths and post-metamorphic exhumation of the Day Nui Con Voi shear zone in Vietnam. Tectonophysics 290 299-318.

Nam, T.N., Sano, Y., Terada, K., Toriumi, M., Quynh, P.V., Dung, L.T., 2001. First SHRIMP U-Pb zircon dating of granulites from the Kontum massif (Vietnam) and tectonothermal implications. Journal of Asian Earth Sciences 19, 77-84.

Nam, T.N., Hyodo, H., Itaya, T., Matsuda, T., 2002. ${ }^{40} \mathrm{Ar} /{ }^{39} \mathrm{Ar}$ single grain dating and mineral chemistry of hornblendes south of the Red River Shear Zone (Vietnam): new evidence for Early Proterozoic tectonothermal event. Gondwana Research 5, 801-811.

Nam, T.N., Toriumi, M., Sano, Y., Terada, K., Thang, T.T., 2003. 2.9, 2.36, 1.96 Ga zircons in orthogneiss south of the Red River shear zone in Viet Nam: evidence from SHRIMP U-Pb dating and tectonothermal implication. Journal of Asian Earth Sciences 21, 743-753.

Nagy, E.A., Maluski, H., Lepvrier, C., Schaerer, U., Phan, Truong Thi, Leyreloup, A., $\mathrm{Vu}$, Van Thich, 2001. Geodynamic significance of the Kontum Massif in central Vietnam: composite ${ }^{40} \mathrm{Ar} /{ }^{39} \mathrm{Ar}$ and $\mathrm{U}-\mathrm{Pb}$ ages from Paleozoic to Triassic. Journal of Geology 109 (6), 755-770.

Nguyen, Trong Yem, 1986. Recent geodynamics of Red River faults system. In: Proceedings of the First Conference. Geology of Indochina, vol. 1. General Department of Geology of Vietnam, Hanoi, pp. 405-408.

Passchier, C.W., Trouw, R.A.J., 1996. Microtectonics. Springer, Germany.

Platt, J.P., 1979. Extensional crenulation cleavage. Journal of Structural Geology 1, 95.

Platt, J.P., Vissers, R.L.M., 1980. Extensional structures in anisotropic rocks. Journal of Structural Geology 2, 397-410.

Platt, J.P., 1984. Secondary cleavages in ductile shear zones. Journal of Structural Geology 6, 439-442.

Ponce De Leon, M.I., Choukroune, P., 1980. Shear zones in the Iberian arc. Journal of Structural Geology 2, 63-68.

Powell, C.McA, 1979. A morphological classification of rock cleavage. Tectonophysics $58(1-2), 21-34$

Rangin, C., Klein, M., Rouques, D., Le Pichon, X., Trong, Le Van, 1995. The Red River fault system in the Tonkin Gulf, Vietnam. Tectonophysics 243, 209-222.

Ramsay, J.G. 1967. Folding and Fracturing of Rocks. McGraw Hill, New York.

Replumaz, A., Tapponnier, P., 2003. Reconstruction of the Deformed Collision Zone Between India and Asia by Backward Motion of Lithospheric Blocks. Jouranl of Geophysical Research 108 (B6), 2185, doi:10.1029/2001JB000661.

Roger, F., Leloup, P.H., Jolivet, M., Lacassin, R., Trinh, P.T., Brunel, M., Seward, D., 2000. Unraveling a long and complex thermal history by multi-system geochronology: example of the Song Chay metamorphic dome, North Vietnam. Tectonophysics 321, 449-466.

Royden, L.H., Burchfiel, B.C., King, R.W., Wang, E., Chen, Z., Shen, F., Liu, Y., 1997 Surface deformation and lower crustal flow in eastern Tibet. Science 276, 788-790.

Scharer, U., Tapponnier, P., Lacassin, R., Leloup, P., Zhong, H.D., Ji, S., 1990. Intraplate tectonics in Asia: a precise age for large-scale Miocene movement along the Ailao Shan-Red River shear zone, China. Earth Planet Science Letters 97, $65-77$.

Scharer, U., Zhang, L.S., Tapponnier, P., 1994. Duration of strike-slip movements in large shear zones: the Red River complex, China. Earth and Planetary Science Letters 126, 379-397.

Simpson, C., Schmid, S.M., 1983. An evaluation of criteria to deduce the sense of movement in sheared rocks. Geological Society of America Bulletin 94, 1281-1288.

Searle, M.P., 2006. Role of the Red River Shear Zone, Yunnan and Vietnam, in the continental extrusion of SE Asia. Journal of the Geological Society, London 163, 1025-1036.

Searle, M.P., 2007. Reply to Discussion by Leloup, Lacassin and Tapponnier: role of the Red River Shear Zone, Yunnan and Vietnam, in the continental extrusion of SE Asia. Journal of the Geological Society, London 164, 1253-1260.

Tapponnier, P., Peltzer, G., Armijo, R., Le Dain, A.Y., Cobbold, P., 1982. Propagating extrusion tectonic in Asia: new insights from simple experiments with plasticine. Geology 10, 611-616.

Tapponnier, P., Peltzer, G., Armijo, R., 1986. On the mechanics of the collision between India and Asia. In: Coward, M.P., Ries, A.C. (Eds.), Collision Tectonics. Geological Society Special Publication, 19, pp. 115-157.

Tapponnier, P., Lacassin, R., Leloup, P.H., Scharer, U., Zhong, D., Liu, X., Ji, S., Zhang, L., Zhong, J., 1990. The Ailao Shan/Red River metamorphic complex: Tertiary leftlateral shear between Indochina and South China. Nature 343, 431-437.

Viola, G., Anczkiewicz, R., 2008. Exhumation history of the Red River shear zone in northern Vietnam: new insights from zircon and apatite fission-track analysis. Journal of Asian Earth Sciences 33, 78-90.

Wang, E., Burchfiel, B.C., 1997. Interpretation of Cenozoic tectonics in the rightlateral accommodation zone between the Ailao Shan Shear Zone and the eastern Himalayan syntaxes. International Geological Reviews 39, 191-219.

Wang, P.L., Lo, C.H., Lee, T.Y., Chung, S.L., Yem, N.T., 1998. Thermochronological evidence for the movement of the Ailao Shan-Red River shear zone: a perspective from Vietnam. Geology 26, 887-890.

Wang, P.L., Lo, C.H., Chung, S.L., Lee, T.Y., Lan, C.Y., Thang, T.V., 2000. Onset timing of left-lateral movement along the Ailao Shan-Red River shear Zone: ${ }^{40} \mathrm{Ar} /{ }^{39} \mathrm{Ar}$ dating constraint from the Nam Dinh area, northeastern Vietnam. Journal of Asian Earth Sciences 18, 281-292.

Wang, P.L., Lo, C.H., Lee, T.Y., Chung, S.L., Yem, N.T., 2001. Reply to comment on "Onset of the movement along the Ailao Shan-Red river shear zone: constraint from ${ }^{40} \mathrm{Ar} /{ }^{39} \mathrm{Ar}$ dating results for Nam Dinh area, northern Vietnam" by Wang et al., Journal of Asian Earth Sciences 18, 281-292. Journal of Asian Earth Sciences 20,101-103.

White, S.H., 1979. Grain and sub-grain size variations across a mylonite zone. Contribution of Mineral Petrology 70, 193-202.

Yeh, M.W., 2007. Deformation sequence of Baltimore gneiss domes, USA, assessed from porphyroblast foliation intersection axes. Journal of Structural Geology 29, 881-897.

Zhao, S., 1995. Detection of the active segment at the Red River fault zone by inversion of observed gravity changes. Journal of Geodynamics 20 (1), 41-62. 